Soares, S.; Freitas, N.; Nepomuceno, E.; Pereira, E.; Sena-Cruz, J. (2020) “Assessment of GFRP bond behaviour for the design of sustainable reinforced seawater concrete structures” Construction \& Building Materials, 231, 117277 1-17.

DOI: $10.1016 /$ j.conbuildmat.2019.117277

\title{
ASSESSMENT OF GFRP BOND BEHAVIOUR FOR THE DESIGN OF SUSTAINABLE REINFORCED SEAWATER CONCRETE STRUCTURES
}

\author{
Sérgio Soares ${ }^{1}$, Nelson Freitas ${ }^{1}$, Emanuel Pereira $^{1}$, Eduarda Nepomuceno ${ }^{1}$, Eduardo Pereira ${ }^{1}$, José Sena-Cruz $^{1 *}$ \\ ${ }^{1}$ ISISE, IB-S, University of Minho, Department of Civil Engineering, \\ Campus de Azurém, 4810-058 Guimarães, Portugal \\ *E-mail: jsena@civil.uminho.pt; Corresponding author
}

\begin{abstract}
Freshwater is an increasingly scarce resource. Its use in the production of concrete is one important contributor to its fast depletion. Alternatively, the use of seawater for reinforced concrete production, combined with the use of glass fibre reinforced polymers (GFRP) as reinforcement, may represent an interesting solution to increase concrete sustainability. The objective of this paper is to explore this promising solution through the development of concrete compositions with seawater. Additionally, it is also an objective to assess the bond behaviour between GFRP rods and concrete, in a design perspective. The influence of concrete age, rod diameter and anchorage length were also investigated. An analytical model capable of determining the local bond stressslip laws was used. Results demonstrated that the use of seawater had no relevant effects on neither concrete mechanical properties nor bond behaviour.
\end{abstract}

Keywords: Concrete; Seawater; GFRP rods; Bond behaviour; Direct pullout tests; Analytical model. 
Soares, S.; Freitas, N.; Nepomuceno, E.; Pereira, E.; Sena-Cruz, J. (2020) “Assessment of GFRP bond behaviour for the design of sustainable reinforced seawater concrete structures” Construction \& Building Materials, 231, 117277 1-17.

DOI: 10.1016/j.conbuildmat.2019.117277

\section{INTRODUCTION}

Water is an indispensable natural resource for the existence of life on planet, holding enormous environmental, economic and social value. Preserving water and promoting its conscious use are essential to guarantee the life quality and protecting future generations [1]. About $80 \%$ of the Earth's surface is occupied by the oceans, which means that almost $98 \%$ of the water on the planet is salty. From the remaining $2 \%$ freshwater available in the planet, only about $1 \%$ is at the surface [2]. Nowadays, with the increase of the population and the consequent increase of pollution, changes in consumption patterns, as well as climate changes, freshwater is an increasingly sought-after resource [3]. According to some studies, about 4.3 billion people face severe water shortage situations [4]. Construction industry, particularly the concrete production, consumes large quantities of freshwater and it becomes crucial to explore new strategies for the water resources preservation namely the possibility to use seawater directly in the design of reinforced concrete $(\mathrm{RC})$ structures that is of great potential and has been proving to be very promising $[5,6]$. On the other hand, there are several RC structures of important economic and social impact located in the maritime environment (ports, bridges, coastal defence structures and offshore structures) which are subjected to the simultaneous action of several physical and chemical deterioration processes that accelerate its degradation, reduce its service life, apart from increasing its maintenance costs [7]. Among others, corrosion of the steel reinforcement and degradation of the concrete cover layer are the most catastrophic effects that result from the exposure to the typically high chlorides and sulphates concentrations [8-10]. Nevertheless, the emergence of fibre reinforced polymers (FRP) and the replacement of conventional steel by these new materials may be the key to prevent the main damages that aggressive agents would cause in steel reinforcement, since these are not susceptible to corrosion and may allow seawater to be directly used in the concrete composition. Besides that, FRP materials have other advantages such as the high tensile strength, low weight, low thermal conductivity and good fatigue behaviour [11, 12]. The market offers several options in terms of FRP rods for reinforced concrete structures, depending on the fibre type: Glass FRP (GFRP), Basalt FRP (BFRP) and Carbon (CFRP) [13-15]. In this research the use of Glass FRP (GFRP) rods as reinforcement of concrete produced with seawater is be analysed, due to their cost-effectiveness when compared with CFRP and BFRP. This topic requires dedicated studies to understand the consequences of using seawater in concrete elements reinforced with GFRP since scientific knowledge in this area is still limited.

In a study recently carried out [16], the authors evaluated the effect of chloride ions exposure on the structural behaviour of GFRP RC columns, aiming at simplifying their practical application to maritime environment. In this 
Soares, S.; Freitas, N.; Nepomuceno, E.; Pereira, E.; Sena-Cruz, J. (2020) “Assessment of GFRP bond behaviour for the design of sustainable reinforced seawater concrete structures” Construction \& Building Materials, 231, $1172771-17$.

DOI: 10.1016/j.conbuildmat.2019.117277

experimental work, the effect of the use of seawater in concrete composition was also studied. The authors concluded that the use of seawater in the concrete composition does not significantly reduce the compressive strength of the test specimens. Furthermore, when subjected to a saline environment, slight reductions in the compressive strength and ductility were recorded, indicating that GFRP rods guaranteed effective confinement of the concrete core even in a high chloride concentration level environment for a prolonged period.

Some research work has been dedicated to the study of the durability of GFRP rods when exposed to aggressive environments. The results have demonstrated that the GFRP rods exhibit good durability and corrosion resistance and it has been recognized that the maritime environment has no significant influence on its mechanical properties $[17,18]$. In its turn, some authors have studied concrete produced with seawater and compared its behaviour with the conventional concrete produced with freshwater [5, 6, 19-23]. The existing studies have shown that the use of seawater has a negligible effect on the concrete carbonation process. Furthermore, the results have revealed that the use of seawater may lead to the increase of concrete's compressive strength at early age, reducing setting time and improving mechanical properties, besides providing similar strength at 28 days of age and in the long-term [5, $20,21]$.

On the other hand, the structural behaviour of conventional concrete elements (freshwater in the composition) reinforced with GFRP rods has been extensively studied, mainly focusing the (i) bond characterization between GFRP and concrete, as well as (ii) the flexural and shear behaviour in full-scale RC elements. In terms of bond characterization, a literature review on the topic can be found in [24]. Several studies have been focused on the long-term bond behaviour through accelerated ageing tests in concrete specimens reinforced with GFRP rods. Typically, in these studies, direct pullout tests were carried out after exposing the specimens to distinct environmental condition [25-27], in order to understand the effect of (i) high temperatures, (ii) tap water immersion, (iii) alkaline and saline solutions and (iv) freeze-thaw cycles. In general, a good bond behaviour was observed when the specimens were exposed to a saline solution over time. In its turn, some authors have focused their scientific research on the structural behaviour of full-scale RC beams. Some of these investigations were focused on short-term behaviour in order to study the instantaneous behaviour of RC beams with GFRP, as opposed to conventional steel reinforcement, in order to understand which parameters most influence its structural response, namely the rod type, the adopted reinforcement rate, the concrete compressive strength and the concrete cover [28-31]. In contrast, recognizing the good structural instantaneous behaviour of the RC beams, some research 
Soares, S.; Freitas, N.; Nepomuceno, E.; Pereira, E.; Sena-Cruz, J. (2020) “Assessment of GFRP bond behaviour for the design of sustainable reinforced seawater concrete structures” Construction \& Building Materials, 231, 117277 1-17.

DOI: 10.1016/j.conbuildmat.2019.117277

has also been carried out on the study of its long-term behaviour, allowing to understand which parameters most influence creep, namely the amount of longitudinal reinforcement and the applied sustain load level [32].

According to the studies carried out, the use of GFRP rods in RC structures exposed to maritime environments shows to be a very promising solution, not only due to the resulting structural performance but also for promoting environmental sustainability. This paper is part of an ongoing research project developed by the authors that aims to explore the use of seawater in RC production when the conventional steel reinforcement is replaced by GFRP rods. This project includes the study of the bond behaviour between GFRP and seawater concrete at both shortand long-term. In fact, the key to the good performance of the concrete/GFRP composite system lies on its adhesion mechanisms that have the main objective to ensure the stress transfer between these two different materials. This aspect is even more important to be carefully investigated when seawater is used in the concrete composition, since this type of water has an important mineralogical component, salts and organic matter that can alter the bond behaviour. Apart from the long-term study, the analysis of the bond behaviour at early ages, when the development of adhesion mechanisms occurs, becomes very important since structures need to be operational at that moment. It is precisely in the short-term bond behaviour that this paper focuses. The research presented includes two main phases: (i) development of concrete compositions through an optimization algorithm to obtain specific properties at fresh and hardened states and (ii) assessment of the bond behaviour between GFRP rods and the developed concrete using direct pullout tests. In this second phase, the influence of concrete age, GFRP rod diameter and anchorage length were also investigated. Besides the experimental investigation, an analytical model capable of determining the local bond stress-slip law which governs the bond behaviour was used for determining the maximum pullout forces as function of the anchorage length.

\section{EXPERIMENTAL PROGRAM}

\subsection{Concrete composition development}

The procedure used to determine the concrete composition is described in this section. This final composition was then used in the production of the specimens to bond characterization. The objective of this development was to find out the best dosages to produce a concrete with mechanical properties required in special projects, particularly in maritime environments. Additionally, considering the overall goal of developing sustainable pathways to improve sustainability of reinforced concrete solutions for maritime environment, the optimization procedure was applied in order to allow maximizing strength without significant amounts of cement. The requirements included: 
Soares, S.; Freitas, N.; Nepomuceno, E.; Pereira, E.; Sena-Cruz, J. (2020) “Assessment of GFRP bond behaviour for the design of sustainable reinforced seawater concrete structures” Construction \& Building Materials, 231, 117277 1-17.

DOI: 10.1016/j.conbuildmat.2019.117277

(i) good workability at fresh state, (ii) high mechanical strength at hardened state and (iii) lower cement contents.

The concrete characterization was carried out in two stages: (i) fresh state by slump-flow test and (ii) hardened state by compressive strength determination.

The concrete composition is mainly influenced by two parameters: (i) particle size distribution of the aggregates and (ii) water/cement (w/c) ratio. The solid skeleton plays a preponderant role in the concrete properties, not only on the mechanical properties but also on the concrete workability in the fresh state. The concrete composition was defined based on the work carried out in [33], using the modified expressions method proposed by Andreasen and Andersen. This method considers the granulometric classification of all solid components according to the Eq. (1), where $D$ represents the sieve size used in the grading size analysis, $D_{\min }$ and $D_{\max }$ are the minimum and maximum particle size, respectively, and $q$ represents the distribution modulus (ratio between fine and coarse particles). The utilization of these expressions has already been demonstrated in some research works [34].

$$
P(D)=\frac{D^{q}-D_{\min }^{q}}{D_{\max }^{q}-D_{\min }^{q}}
$$

Based on some preliminary studies, $q$ value was assumed to equal to 0.3 and the binder content $480 \mathrm{~kg} / \mathrm{m}^{3}$, since the objective was to obtain a concrete with high mechanical strength. The materials used in concrete composition were: (i) water, (ii) binder (Portland cement CEM I 42.5R conforming to European standard NP EN 197-1:2001 [35]), (iii) aggregates (sand, gravel 4-8 and gravel 8-16), (iv) type II addition (fly ashes) and (v) admixtures (superplasticizer - Sika ${ }^{\circledR}$ ViscoCrete ${ }^{\circledR} 3002 \mathrm{HE}$ and viscosity controlling agent - Sika ${ }^{\circledR}$ VP1). The aggregates were carefully selected and previously washed (see Figure 1). According to the standard NP EN 933-1:2000 [36], the sieve analysis was performed, and the respective curves are presented in the Figure 2 (a). Up to final solution, an iterative process was carried out considering the constituent materials of the concrete matrix solid component. This iterative adjustment process was based on the least squares' method. The optimum adjustment found to the reference curve is depicted in Figure 2 (b). The amount of fly ashes used was also determined in the same iterative process. In the case of the admixtures, the amount of superplasticizer and viscosity controlling agent introduced in the mixture was $1 \%$ of the cement mass, as recommended by the manufactures.

Once the solid skeleton was defined, the next step was the analysis of the water/cement (w/c) ratio influence. In order to do so, four different mixtures (M1, M2, M3 and M4) were produced with different w/c ratios $(0.30,0.27$, 0.26 and 0.25 , respectively) 
Soares, S.; Freitas, N.; Nepomuceno, E.; Pereira, E.; Sena-Cruz, J. (2020) “Assessment of GFRP bond behaviour for the design of sustainable reinforced seawater concrete structures” Construction \& Building Materials, 231, 117277 1-17.

DOI: 10.1016/j.conbuildmat.2019.117277

In order to characterize the properties of the concrete in the fresh state, slump-flow tests were carried out and the $\mathrm{T}_{500}$ parameter was measured, according to the standard BS EN 12350-8:2010 [37]. This test allows the evaluation of the fresh deformability of the concrete through the deformation velocity and slump flow diameter imposed by the action of self-weight. The $\mathrm{T}_{500}$ parameter allows to indirectly assess the concrete viscosity. The results are presented in Table 1. According to the observed results, the following conclusions can be drawn: (i) some free water was observed on M1 surface which did not adhere to the particles surface of the concrete matrix (too high w/c ratio), (ii) M4 showed to be excessively compact, viscous and with low workability due to the need of more water to not only moisturize cement but also to connect the concrete matrix and (iii) M2 and M3 demonstrated to be more fluid with suitable workability and without segregation signs.

To evaluate the concrete properties in hardened state, compression tests were performed according to the standard NP EN 12390-3:2011 [38]. The purpose was to access the average compressive strength $\left(f_{\mathrm{cm}, 7}\right)$ of the different concrete compositions. For each mixture, four cylinders of $150 \mathrm{~mm}$ of diameter and $300 \mathrm{~mm}$ of height were tested. The tests were performed at 7 days of concrete age. All concrete specimens were cured in a wet environment, fully immersed in a water tank at a temperature of $22 \pm 2{ }^{\circ} \mathrm{C}$ until the testing day. According to NP EN 1992-1-1:2010 [39] and based on the results obtained at 7 days of age, the compressive strength at 28 days of age $\left(f_{\mathrm{cm}, 28}\right)$ was estimated. The obtained results are presented in Table 2. Based on these results, M4 composition (lower w/c) presented the highest compressive strength.

Considering all the results, M3 composition $(\mathrm{w} / \mathrm{c}=0.26)$ was selected as the final mix, with the following constituents: (i) cement CEM I 42.5R according to European standard NP EN 197-1:2001 (480 kg/m³), (ii) classf fly ash $\left(124.5 \mathrm{~kg} / \mathrm{m}^{3}\right)$, (iii) sand $\left(1271 \mathrm{~kg} / \mathrm{m}^{3}\right)$, (iv) gravel $4-8\left(192 \mathrm{~kg} / \mathrm{m}^{3}\right)$, (v) gravel $8-16\left(76.7 \mathrm{~kg} / \mathrm{m}^{3}\right)$, (vi) superplasticizer Sika®ViscoCrete ${ }^{\circledR} 3002 \mathrm{HE}\left(5.1 \mathrm{~kg} / \mathrm{m}^{3}\right)$ and (vii) viscosity modifying agent Sika® VP1 $\left(4.8 \mathrm{~kg} / \mathrm{m}^{3}\right)$. This composition was adopted to produce the specimens to be used in the direct pullout tests.

\subsection{Direct pullout tests: test program, experimental set-up and instrumentation}

The main objective of the second phase of this exploratory research was to experimentally characterize the bond behaviour between GFRP rods and concrete, as well as to compare these results when either seawater (SW) or tap water (TW) were used in the production of the concrete specimens. For this purpose, the concrete composition described in the previous section were employed. The experimental program, as presented in Table 3, was composed of 48 direct pullout tests divided into 16 series. The studied parameters were the following: (i) water 
Soares, S.; Freitas, N.; Nepomuceno, E.; Pereira, E.; Sena-Cruz, J. (2020) “Assessment of GFRP bond behaviour for the design of sustainable reinforced seawater concrete structures” Construction \& Building Materials, 231, 117277 1-17.

DOI: 10.1016/j.conbuildmat.2019.117277

type used in the concrete composition ( $\mathrm{SW}$ or TW), (ii) curing time of the concrete at the testing date (7 or 28 days), (iii) GFRP diameter ( $\varnothing 8$ or $\varnothing 12)$ and (iv) anchorage length (5Ø or $10 \varnothing)$. It is well known that the GFRP bar size greatly affects the bond behavior and bond strength. In this work only two diameters ( 8 and $12 \mathrm{~mm})$ were adopted, which are not representative of all the range of bar sizes available in the market. This option was followed (i) take advantage of the existing knowledge with a previously existing test setup and focus on the seawater influence as the main study variable; (ii) emphasis was more on the study of the complete protocol for assessing the bond behavior of GFRP bars in concrete made with seawater, which can now be extended to other bar diameters; (iii) keep the number of studied variables reasonable. The SW used in the concrete production was extracted directly from the sea, more specifically from Esposende (north coast of Portugal). According to laboratory analyses carried out by APA-ARH Norte (Portuguese Environment Agency), the water quality was rated as excellent, without chemical pollutants. The salinity of SW, i.e. salt concentration per unit mass of water was about $3.5 \%$ [40].

The anchorage length was materialized by introducing a plastic tube in the desired non-adhered zone of each GFRP rod, unlike to the remaining rod length that was in direct contact with the concrete. The function of the plastic tube was to ensure absence of contact between the GFRP rod and the fresh concrete at the zones out of the anchorage length zones (see Figure 3) during casting. The correct positioning of the plastic tubes in the GFRP rods was guaranteed using a soft silicone glue.

The designation of each series was defined as follows: (i) "TW" or "SW" states the type of water used in concrete composition, (ii) " $\mathrm{D}$ " is the curing time of the concrete at the testing date (7 or 28 days), (iii) " $\emptyset$ " is the GFRP rod nominal diameter in millimetres ( $\varnothing 8$ or $\varnothing 12$ ), (iv) "LbXØ” is the anchorage length where $\mathrm{X}$ is the multiple of the GFRP rod nominal diameter (5 or 10$)$, and (v) " $\mathrm{i}$ " is the specimen order number tested under the same conditions $(1,2,3)$. Figure 4 shows the schematics of the test set-up adopted for the present experimental program. Concrete cubic blocks with $200 \mathrm{~mm}$ of edge were used. During the direct pullout test, the applied force was measured with a load cell of $200 \mathrm{kN}(0.05 \%$ F.S.) maximum capacity. The relative displacement between the GFRP and the concrete (slip) at the loaded end section was assessed by the average of displacements measured by LVDTs 1,2 and 3, positioned at $120^{\circ}$ around the GFRP rod and considering the elastic deformation of the GFRP between the loaded end section and the section where the support of the LVDTs was installed (50 mm apart to the concrete block surface - see Figure 4). Free end slip was assessed using LVDT 4. LVDTs 1 and 2 had a stroke of $\pm 10 \mathrm{~mm}$ 
Soares, S.; Freitas, N.; Nepomuceno, E.; Pereira, E.; Sena-Cruz, J. (2020) “Assessment of GFRP bond behaviour for the design of sustainable reinforced seawater concrete structures” Construction \& Building Materials, 231, 117277 1-17.

DOI: $10.1016 /$ j.conbuildmat.2019.117277

(0.25\% F.S.). LVDT 3 and 4 had a stroke of $\pm 5 \mathrm{~mm}(0.25 \%$ F.S.). The direct pullout tests were performed under displacement control at the testing machine head, with an imposed displacement rate of $0.021 \mathrm{~mm} / \mathrm{s}$.

\section{MATERIAL CHARACTERIZATION}

The material characterization included the assessment of the mechanical properties of the materials involved in bond characterization test program, namely: (i) GFRP rods and (ii) concrete in the fresh and hardened state (TW and SW concrete). It should be highlighted that the concrete composition used in the casting of test specimens was the concrete composition obtained in the research phase of the concrete composition development presented in Section 2.1.

\subsection{GFRP rods}

To reinforce the concrete specimens, ComBAR® GFRP ribbed round rods produced by the company Schöck were used. These are manufactured through the pultrusion process where the impregnation and saturation of the glass fibres with vinyl-ester resin is carried out under pressure, allowing a volume fraction of fibres higher than $85 \%$. This type of rod presents a deformed external surface with ribs of a constant height of $6 \%$ of bar diameter and a spacing of about $8.5 \mathrm{~mm}$. As stated previously, two different diameters of this specific type of GFRP rod were studied $(8$ and $12 \mathrm{~mm})$. The tensile mechanical properties of these rods were assessed according to the ASTM D7205/D7205M:2006 [41] by conducting uniaxial tensile tests under displacement control at a rate of $4 \mathrm{~mm} / \mathrm{s}$. From six GFRP rods of each diameter, the average modulus of elasticity $\left(E_{\mathrm{f}}\right)$, the average tensile strength $\left(f_{\text {ult }}\right)$ and the average ultimate strain $\left(\varepsilon_{\mathrm{f}}\right)$ were obtained. The test specimen's instrumentation included the measurement of the applied tensile load and the strain in the rod longitudinal axis at middle height. Figure 5 (a) and (b) show the uniaxial test set-up used as well as a typical failure mode observed, respectively. During the uniaxial tests, it was possible to observe that with the increase of the applied tensile force the ribs began to separate from the rod core followed by the total and abrupt tensile failure. Table 4 shows the obtained average results.

\subsection{Concrete}

To produce the concrete for the direct pullout test specimens, eight concrete batches were produced: four with seawater (SW) and the others with tap water (TW). The concrete was characterized in two different phases: (i) fresh state and (ii) hardened state (at 7 and 28 days of age). In both of characterization phases, the influence of the water used in the concrete composition was analysed. 
Soares, S.; Freitas, N.; Nepomuceno, E.; Pereira, E.; Sena-Cruz, J. (2020) “Assessment of GFRP bond behaviour for the design of sustainable reinforced seawater concrete structures” Construction \& Building Materials, 231, 117277 1-17.

DOI: 10.1016/j.conbuildmat.2019.117277

\subsubsection{Fresh state concrete}

To characterize the concrete properties in the fresh state, slump-flow test was done and the $\mathrm{T}_{500}$ parameter was measured, according to the standard BS EN 12350-8:2010 [37]. Table 5 presents the obtained results. These results show that when SW was used in the mixture, the concrete exhibited a more cohesive, viscous and compact behaviour compared to the mixture where TW was incorporated. Consequently, the SW concrete presented less workability than the TW concrete, and for that reason it was not possible to obtain the $\mathrm{T}_{500}$ parameter (concrete casting 2 and 3) because the fluid concrete did not reach a flow diameter of $500 \mathrm{~mm}$. However, all concrete mixtures did not show any sign of segregation and maintained an adequate homogeneity. Additionally, the results seem to suggest that the use of SW in the mixture may have reduced concrete setting time and led to the faster development of its mechanical properties. Similar observations were made in other research studies [5, 20, 21, 23] and the possible explanation is the acceleration of hydration process due to the presence of chloride.

\subsubsection{Hardened state concrete}

To characterize the concrete properties in the hardened state, compression tests were carried out with concrete cylindrical specimens with $150 \mathrm{~mm}$ of diameter and $300 \mathrm{~mm}$ of height. The compression tests were performed at 7 and 28 days after casting to obtain the average compressive strength $\left(f_{\mathrm{cm}}\right)$ and modulus of elasticity $\left(E_{\mathrm{cm}}\right)$, according NP EN 12390-3:2011 [38] and LNEC E397:1993 [42], respectively. All concrete specimens (cylinders for concrete characterization tests and cubes for direct pullout tests) were cured in a wet environment, fully immersed in a water tank at a temperature of $22 \pm 2^{\circ} \mathrm{C}$ until the testing day. The water type used to immerse the test specimens match the water type used in the corresponding concrete composition. In total, 16 cylindrical specimens were tested among which 4 specimens under the same conditions: same water type (TW or SW) and same age (7 or 28 days). Table 6 summarizes the obtained results whereas in Figure 6 the mechanical properties of the concretes produced with different water types are compared.

The concrete produced with SW at 7 days of age presents a slightly higher compressive strength (54.5 MPa) when compared to the concrete produced with TW (50.5 MPa). As the concrete characterization results in fresh state seemed to suggest, the mechanical properties evolution is slightly faster in the case of SW concrete which means that this type of water may have reduced the concrete setting time. Similar observations were made in other research studies [5]. 
Soares, S.; Freitas, N.; Nepomuceno, E.; Pereira, E.; Sena-Cruz, J. (2020) “Assessment of GFRP bond behaviour for the design of sustainable reinforced seawater concrete structures” Construction \& Building Materials, 231, $1172771-17$.

DOI: 10.1016/j.conbuildmat.2019.117277

Nevertheless, after 7 days, the mechanical properties evolution of the SW concrete tends to be slower, thus exhibiting values of compressive strength of smaller magnitude over time. So, at 28 days of age, the concrete produced with TW presented higher mechanical properties than the concrete with SW. This may be justified by the fact that SW contains several mineral and biological elements that can interact with concrete components and consequently influence their properties. The results show that when SW was used, a lower average compressive strength $\left(f_{\mathrm{cm}}\right)$ was obtained (58.0 MPa) comparatively to the use of TW (66.5 MPa). A similar trend was observed in terms of modulus of elasticity: when SW was used, an average modulus of elasticity $\left(E_{\mathrm{cm}}\right)$ of $33.4 \mathrm{GPa}$ was obtained whereas the use of TW has resulted in an average modulus of elasticity of $36.3 \mathrm{GPa}$. According to EN 1992-1-1:2010 [39], the concrete with SW complies with the strength class C50/60 while the concrete with TW in its composition complies with the strength class C55/67.

\section{BOND BEHAVIOUR - RESULTS AND DISCUSSION}

\subsection{Main results}

In this section the main results obtained in the direct pullout tests are presented. Table 7 summarizes the average results for each series through several parameters that characterize the bond behaviour between the GFRP rods and the concrete, namely: $F_{\max }$ is the maximum pullout force; $s_{\operatorname{lmax}}$ and $s_{\mathrm{fmax}}$ are the loaded and free end slips obtained at the $F_{\max }$, respectively; $\tau_{\max }$ represents the average shear strength assuming a constant shear stress along the anchorage length (ratio between $F_{\max }$ and contact area between the GFRP and concrete); $F_{\mathrm{r}}$ is the residual pullout force corresponding to a $s_{1}$ of $10 \mathrm{~mm} ; G_{\mathrm{f}}$ is the fracture energy during the debonding process up to $10 \mathrm{~mm}$ of $s_{1} ; F_{\mathrm{r}} / F_{\max }$ represents the ratio between residual pullout force $\left(F_{\mathrm{r}}\right)$ and the maximum pullout force $\left(F_{\max }\right)$; FM represents the failure mode observed in the test. The average value of the test specimen's concrete compressive strength $\left(f_{\mathrm{cm}}\right)$ of each series is also included in Table 7. For each reading, the loaded end slip, $s_{1}$ (in [mm]), was calculated by the subtraction of the elastic deformation of the GFRP bar to the LVDT readings, according to Eq. (2), where $\delta_{\operatorname{LVDT} 1,2,3}$ (in [mm]) is the average value of readings given by LVTDs 1,2 and $3, F_{l}$ (in [N]) is the pullout force and $E_{\mathrm{f}}$ (in $[\mathrm{MPa}]$ )and $A_{\mathrm{f}}\left(\right.$ in $\left[\mathrm{mm}^{2}\right]$ ) are the Young modulus and the cross-section area of the GFRP bar, respectively. Additionally, to account for the different values of the concrete compressive $\left(f_{\mathrm{cm}}\right)$ and tensile $\left(f_{\mathrm{ctm}}\right)$ strengths, normalized values of maximum pullout force $\left(\bar{F}_{\max }\right)$, shear strength $\left(\bar{\tau}_{\max }\right)$ and fracture energy $\left(\bar{G}_{\mathrm{f}}\right)$ were also calculated according to Eq. (3), Eq. (4) and Eq. (5), respectively. In these equations, $P_{\mathrm{f}}$ and $L_{\mathrm{b}}$ represent the GFRP rod perimeter and the anchorage length adopted in the corresponding test series, respectively. These 
Soares, S.; Freitas, N.; Nepomuceno, E.; Pereira, E.; Sena-Cruz, J. (2020) “Assessment of GFRP bond behaviour for the design of sustainable reinforced seawater concrete structures” Construction \& Building Materials, 231, 117277 1-17.

DOI: 10.1016/j.conbuildmat.2019.117277

entities are also included in Table 7. For each test series, the $f_{\text {ctm }}$ value was estimated according to the recommendations given in NP EN 1992-1-1:2010 [39].

$$
\begin{aligned}
& s_{\mathrm{l}}=\delta_{\mathrm{LVDT} 1,2,3}-\frac{F_{l} \cdot\left(250-L_{\mathrm{b}}\right)}{E_{\mathrm{f}} \cdot A_{\mathrm{f}}} \\
& \bar{F}_{\text {max }}=F_{\text {max }} /\left(f_{\mathrm{ctm}} \cdot P_{\mathrm{f}} \cdot L_{\mathrm{b}}\right) \\
& \bar{\tau}_{\text {max }}=\tau_{\text {max }} / f_{\mathrm{ctm}} \\
& \bar{G}_{\mathrm{f}}=G_{\mathrm{f}} /\left(f_{\mathrm{ctm}} \cdot P_{\mathrm{f}} \cdot L_{\mathrm{b}} \cdot 10\right)
\end{aligned}
$$

From a general analysis, it is possible to verify that when tap water (TW) was used in the concrete composition instead of seawater (SW), higher values of $\bar{F}_{\max }, s_{\operatorname{lmax}}, \bar{\tau}_{\max }$ and $\bar{G}_{\mathrm{f}}$ were obtained at 28 days of age. Moreover, the influence of the GFRP rod diameter used can also be verified from: when a higher rod diameter was used, higher values of $F_{\max }, s_{\operatorname{lmax}}, \tau_{\max }$ and $G_{\mathrm{f}}$ were obtained. In its turn, the $L_{\mathrm{b}}$ adopted also showed to have influence on the bond behaviour. With the increase of $L_{\mathrm{b}}$, an increase of $F_{\max }, s_{\operatorname{lmax}}$, and $G_{\mathrm{f}}$ was observed. However, when the highest $L_{\mathrm{b}}$ was used lower values of $\tau_{\max }$ were obtained. In terms of failure modes, in all the tests debonding failure at the GFRP/concrete interface was observed. In some test series this failure mode was accompanied by partial or complete rupture of the GFRP ribs, particularly in the series whose concrete had higher mechanical strength (TW series at 28 days of concrete age). A detailed analysis of these results will be presented subsequently.

Figure 7 shows the relation between the pullout force $(F)$ and loaded end slip $\left(s_{1}\right)$ obtained in all the direct pullout tests. In general, regardless of the concrete age, two distinct phases can be identified in the $F$ - $s_{1}$ curves. The first phase (pre-peak) is characterized by an approximately linear relationship between the applied force and the slip due to the perfect bond. At this phase, the bond adherence provided by the chemical adhesion between the involving materials is responsible for the bond strength. Debonding process starts soon after the linear branch where a loss of adhesion and stiffness is observed close to $F_{\max }$. This process starts when the ultimate shear strength is attained at the beginning of the bonded length, i.e. at the loaded end. The second phase (post-peak) is characterized by a markedly non-linear bond behaviour. Immediately after the $F_{\max }$ has been reached, a downward curve branch with a significant slope is observed, followed by a softer slope in more advanced stages. This last 
Soares, S.; Freitas, N.; Nepomuceno, E.; Pereira, E.; Sena-Cruz, J. (2020) “Assessment of GFRP bond behaviour for the design of sustainable reinforced seawater concrete structures” Construction \& Building Materials, 231, 117277 1-17.

DOI: 10.1016/j.conbuildmat.2019.117277

stage is mainly governed by friction between the involved materials. However, in some cases (e.g. TW_28D_Ø8_Lb5Ø_3, TW_28D_Ø8_Lb10Ø_1,2,3, TW_28D_Ø12_Lb5Ø_2,3) the post-peak branch is characterized by an increase in the residual bond strength with the progressive increase of the GFRP bar slip. In these cases, it is believed that the recorded residual bond load does not necessarily represent the real value of frictional stress developed at the failure interface (frictional bond mechanism) since there is an additional resistance produced by the wedging action of the undamaged bar (mechanical bond mechanism). This phenomenon is usually named as "wedging effect" and is related to the fact that when the damaged part of the FRP bar is pulling out from the concrete, the undamaged part enters in the anchorage length zone (narrower zone) and adds additional mechanical residual bond strength to the pullout load, mainly provided by the ribs of the undamaged GFRP bar. This phenomenon has already been observed in other studies, e.g. [43, 44] and the authors indicated that the wedging effect insignificantly influences the first peak pull-out stress (bond strength) due to the small corresponding free end slip.

It is important to mention that the specimens TW_7D_Ø12_Lb5Ø_2 and TW_7D_Ø12_Lb10Ø_2 were not included in the analysis due to technical problems in data acquisition (except in the identification of the failure mode). In addition, analysing the $F-S_{1}$ curves, two abnormal situations must also be mentioned. The first is that in the specimen SW_7D_Ø12_Lb5Ø_2 there was a disturbance in the test due to slippage of the lashing which induced a loss and a sudden recovery of the pullout force. However, as the slippage occurred in the softening phase, this did not disturb the results analysis since for $s_{1}$ values higher than $7 \mathrm{~mm}$, the pullout test stabilized again. In the second situation (specimens SW_7D_Ø12_Lb10Ø_3, TW_28D_Ø12_Lb10Ø_2, TW_28D_Ø12_Lb5Ø_3 and SW_28D_Ø12_Lb10Ø_2) there was an abrupt drop in the pullout force for an increase in $S_{1}$. This situation may be justified by the high internal damage faced by the concrete compromising an effective response of the adhesion mechanisms. Possibly, the bond mechanism abruptly collapsed immediately after $F_{\max }$ has been reached, and the solid concrete part were not be able to control such sharp slip due to the high pullout force.

\subsection{Failure modes}

The bond response observed in the $F-s_{1}$ curves (Figure 7) is directly related to the bond mechanisms and consequent failure modes. Three different failure modes were observed in the direct pullout test experimental program: (i) debonding failure at the GFRP/concrete interface with complete rupture of GFRP ribs (CR) (see Figure 8 (a) and (b)), (ii) debonding failure at the GFRP/concrete interface with partial rupture of GFRP ribs (PR) (see Figure 
Soares, S.; Freitas, N.; Nepomuceno, E.; Pereira, E.; Sena-Cruz, J. (2020) “Assessment of GFRP bond behaviour for the design of sustainable reinforced seawater concrete structures” Construction \& Building Materials, 231, 117277 1-17.

DOI: 10.1016/j.conbuildmat.2019.117277

8 (c)) and (iii) debonding failure at the GFRP/concrete interface (D) (see Figure 8 (d)). The latter failure mode was the most frequently observed. However, in some tests the typical debonding failure was accompanied by partial or complete rupture of GFRP ribs, where the "wedging effect" may occurred. This phenomenon was explained in the previous section and probably occurred due to the better mechanical properties of the concrete which explains the fact that the PR and CR failure modes had been verified in the specimens tested at 28 days of age for the concrete with the highest compressive strength (TW concrete). In these cases, the resisting mechanisms involved the frictional component and an additional mechanical resistance produced by the wedging action of the undamaged bar.

\subsection{Influence of the studied parameters on the bond behaviour}

In this section, a more detailed analysis of the influence of the study variables on the bond behaviour between the GFRP rod and concrete is carried out. Thus, the influence of the GFRP rods diameter used (Ø8 or $\emptyset 12)$ and the anchorage length adopted ( $5 \varnothing$ or $10 \varnothing)$ on the following parameters is discussed, for both 7 and 28 days of the concrete age (Figure 9 (a)-(c)): (i) maximum pullout force $\left(F_{\max }\right)$, (ii) average shear strength $\left(\tau_{\max }\right)$ and (iii) fracture energy $\left(G_{\mathrm{f}}\right)$. In turn, the influence of the water type used in the concrete composition (SW - seawater or TW - tap water) is analysed both at 7 and 28 days of the concrete age through the following key parameters (Figure 9 (e) and (f)): normalized values of (i) maximum pullout force $\left(\bar{F}_{\max }\right)$ or shear strength $\left(\bar{\tau}_{\max }\right)$ and (ii) fracture energy $\left(\bar{G}_{\mathrm{f}}\right)$. Before proceeding to the discussion of these results, it is important to highlight that the $F_{\mathrm{r}} / F_{\max }$ ratio (see Table 7), was strongly influenced by the failure mode observed. On average, when complete rupture of GFRP ribs was observed at 28 days of concrete age, $F_{\mathrm{r}} / F_{\max }$ ratio increased from $30 \%$ to $100 \%$ (Figure 9 (d)).

\subsubsection{Influence of the GFRP diameter}

Regarding the GFRP diameter, in spite of the GFRP cross section area (or the external surface in contact with concrete) of the rod $\varnothing 12$ being $125 \%$ larger than the one of rod $\varnothing 8$, it was found that $F_{\max }$ and $\tau_{\max }$ has respectively increased about $208 \%$ and $37 \%$ at 7 days and about $173 \%$ and $21 \%$ at 28 days, when $\emptyset 12$ was used instead of $\emptyset 8$ (Figure 9 (a) and Figure 9 (b)). Thus, this showed that the bond strength tends to increase with the increase of the rod diameter (at least from $\varnothing 8$ to $\emptyset 12$ ). Similar trend was also observed in [45] and can be justified by the fact that $\varnothing 12$ rods show larger ribs, thus promoting better bond conditions than $\emptyset 8$ rods. Consequently, higher values were obtained for the $S_{\operatorname{lmax}}$. In terms of $G_{\mathrm{f}}$, a considerable increment was observed (on average about $227 \%$ and $144 \%$ at 7 and 28 days of concrete age, respectively) when $\varnothing 12$ was used instead of $\varnothing 8$ (Figure 9 (c)). 
Soares, S.; Freitas, N.; Nepomuceno, E.; Pereira, E.; Sena-Cruz, J. (2020) “Assessment of GFRP bond behaviour for the design of sustainable reinforced seawater concrete structures” Construction \& Building Materials, 231, 117277 1-17.

DOI: 10.1016/j.conbuildmat.2019.117277

\subsubsection{Influence of the anchorage length}

As expected, results demonstrated that by increasing $L_{\mathrm{b}}$ the bond strength has increased, since the adopted lengths are relatively small (lower than effective anchorage length). On average, it was found that $F_{\max }$ has increased about $72 \%$ and $69 \%$ at 7 and 28 days of age respectively, when $L_{b}=10 \emptyset$ was used instead of $L_{b}=5 \emptyset$ (Figure 9 (a)). On the other hand, by increasing $L_{\mathrm{b}}$, a larger contact surface between reinforcing material and concrete was mobilized and consequently lower $\tau_{\max }$ values were obtained, due to the non-linear distribution of bond stresses along the anchorage length. According to the results, it was found that the $\tau_{\max }$ has decreased about $14 \%$ and $16 \%$ at 7 and 28 days of age respectively, when a $L_{b}=10 \varnothing$ was adopted instead of $L_{b}=5 \varnothing$ (Figure 9 (b)). Furthermore, $s_{1 \max }$ also increased with $L_{\mathrm{b}}$. In terms of $G_{\mathrm{f}}$ at 7 days, increases of about $67 \%$ and $135 \%$ were obtained in the TW and SW series respectively, when a $L_{\mathrm{b}}=10 \varnothing$ was adopted instead of $L_{\mathrm{b}}=5 \emptyset$. At 28 days, $G_{\mathrm{f}}$ increases of about $151 \%$ and $62 \%$ were verified in the $\varnothing 8$ and $\varnothing 12$ series respectively, when a $L_{b}=10 \varnothing$ was adopted instead of $L_{b}=5 \varnothing$ (Figure $9(\mathrm{c}))$.

\subsubsection{Influence of the water type}

In general, the analysis of the results suggested that the use of TW provided a slightly higher bond strength, compared with the use of SW in concrete mixture. In general, the use of TW instead of SW provided an increase of $12 \%$ and $15 \%$ on the $\bar{F}_{\max }$ and $\bar{\tau}_{\max }$ respectively, at 7 and 28 days of concrete age (Figure 9 (e)). It is relevant to note that the higher increments on the $\bar{F}_{\max }$ and $\bar{\tau}_{\max }$ were verified in the series in which a smaller GFRP rod diameter and a shorter $L_{\mathrm{b}}$ were adopted. When $\emptyset 12$ rod was used and a $L_{\mathrm{b}}=10 \varnothing$ was adopted, increases of only $5 \%$ and $8 \%$ were verified respectively at 7 and 28 days of concrete age, when TW was used instead of SW. This slight difference may be explained by the presence of mineral, biological and chemical components on the SW, which may have some effects on the bond behaviour. In terms of $\bar{G}_{\mathrm{f}}$ at 7 days, increases of about $35 \%$ were obtained in the series in which a $L_{b}=5 \varnothing$ was adopted, when TW was used instead of SW, while in the $L_{b}=10 \varnothing$ series no increase was verified. At 28 days, $\bar{G}_{\mathrm{f}}$ increases of about $95 \%$ and $36 \%$ were verified respectively in the $\emptyset 8$ and $\emptyset 12$ series, when TW was used instead of SW (Figure 9 (f)). However, in general it can be considered that the use of SW in the concrete mixture had a minimal impact on the mechanical properties assessed and no relevant effects on the bond behaviour between GFRP and concrete. 
Soares, S.; Freitas, N.; Nepomuceno, E.; Pereira, E.; Sena-Cruz, J. (2020) “Assessment of GFRP bond behaviour for the design of sustainable reinforced seawater concrete structures” Construction \& Building Materials, 231, 117277 1-17.

DOI: 10.1016/j.conbuildmat.2019.117277

\section{ANALYTICAL MODELLING}

The analytical representation of the pullout phenomenon is often expressed by a second order differential equation, which can be established in terms of forces $[46,47]$ or derived in terms of slip [48-50]. In the present work the local bond law was established in terms of slip and obtained by an inverse analysis procedure. A brief overview of the analytical formulation is presented in the current section. A detailed description of the model, as well as the inverse analysis strategy can be found in [49-52]. This strategy has shown a good predictive performance on modelling a diversity of pullout test results, namely near-surface mounted CFRP laminate strips [51, 52], galvanized steel rod [53] and discrete steel fibres embedded in concrete [49].

The main objective in this section is (i) to describe the work developed to determine the local bond stress-slip laws $(\tau-s)$ of the experimental direct pullout tests to better understand the bond behaviour between the GFRP rods and the concrete with different water types (TW and SW) on its composition, and then, (ii) to propose design curves in terms of maximum pullout force $\left(F_{\max }\right)$ versus anchorage length $\left(L_{\mathrm{b}}\right)$ in order to calculate the anchorage length required to reach the maximum capacity of the GFRP rod $\left(L_{b, e f f}\right)$. For this purpose, all the results obtained at 28 days of age of the concrete were numerically simulated.

\section{$5.1 \quad$ Local bond-slip}

From the equilibrium of the free body of an infinitesimal length $d x$ of a GFRP rod bonded to a concrete matrix (see Figure 10) the second order differential equation that governs the local bond phenomena can be established by Eq. (6), where $\tau=\tau[s(x)]$ is the local bond shear stress acting on the contact surface between the GFRP rod and the concrete. $s$ is the slip, i.e., the relative displacement between the GFRP and the surrounding concrete. Additionally, $E_{\mathrm{f}}, A_{\mathrm{f}}$ and $P_{\mathrm{f}}$ are the Young modulus, the cross-sectional area and the perimeter of the GFRP rod, respectively. Assuming that the GFRP rod has a linear elastic behaviour $\left[d \sigma_{\mathrm{f}}=E_{\mathrm{f}} \times d \varepsilon_{\mathrm{f}}\right]$ and neglecting the concrete deformability in the slip assessment, after simplification of Eq. (6), the second order differential equation that governs the local bond phenomena is given by Eq. (7). Based on this second order differential equation, it is possible to obtain $\tau-s$ relationship using an inverse analysis procedure, consisting of a series of iterations in order to find the value of the parameters of this relation which can satisfy the second order differential equation. In this way, the numerical pullout force $(N)$ is determined and then the computed response in terms of pullout force and slip $(N-s)$ achieved based on the parameters selected for the $\tau-s$ law is compared with the corresponding 
Soares, S.; Freitas, N.; Nepomuceno, E.; Pereira, E.; Sena-Cruz, J. (2020) “Assessment of GFRP bond behaviour for the design of sustainable reinforced seawater concrete structures” Construction \& Building Materials, 231, 117277 1-17.

DOI: 10.1016/j.conbuildmat.2019.117277

experimental response $F-s$. Until the $N$-s response is not sufficiently close to the $F-s$, the process must be repeated until a good approximation between the numerical and experimental responses is obtained.

$$
\begin{aligned}
& \sigma_{\mathrm{f}} \cdot A_{\mathrm{f}}+\tau \cdot P_{\mathrm{f}} \cdot d x=\left(\sigma_{\mathrm{f}}+d \sigma_{\mathrm{f}}\right) \cdot A_{\mathrm{f}} \\
& \frac{d^{2} s}{d x^{2}}=\frac{P_{\mathrm{f}}}{E_{\mathrm{f}} \cdot A_{\mathrm{f}}} \cdot \tau(x)
\end{aligned}
$$

\subsection{Pullout force-slip relationship}

Figure 11 illustrates a GFRP rod inserted in concrete over an anchorage length $L_{\mathrm{b}}$, where $N$ is the generic applied pullout force, and $s_{\mathrm{f}}$ and $s_{1}$ are the free and loaded end slips, respectively. When the pullout force $(N)$ is applied and the GFRP rod is slipping, the following functions and parameters can be evaluated along the anchorage length: (i) the slip along the GFRP rod $[s(x)]$, (ii) the bond shear stress along the embedded length $[\tau(x)]$, (iii) the GFRP rod strain $\left(\varepsilon_{\mathrm{f}}\right)$ and (iv) the axial force $N(x)$ where the origin of the $x$ axis coincides with the free extremity of the anchorage length. In Figure 11 the slip diagram along the GFRP rod $[s(x)]$ can be regarded as the sum of two components: a constant component $\left(s_{\mathrm{f}}\right)$ which produces a rigid body displacement of the GFRP rod whereas the $s_{\mathrm{d}}(x)$ component results from the GFRP rod deformation. So, for any point in the anchorage length, just the $s_{\mathrm{d}}(x)$ component will result in a GFRP rod length change, thus the GFRP rod deformation at a point $x$ is obtained by: $\varepsilon_{\mathrm{f}}(x)=N(x) /\left(E_{\mathrm{f}} \times A_{\mathrm{f}}\right)$. The pullout force $(N)$ is given by Eq. (8) which is obtained by equalling the internal and the external work produced by the GFRP rod elastic deformation and the bond stress profile at the GFRP interface, respectively [53]. To solve the Eq. (8), the analytical bond $\tau-s$ relationship defined by the Eq. (9) was used in the present work. In this equation, $\tau_{\mathrm{m}}$ and $s_{\mathrm{m}}$ are the bond strength and its corresponding slip, respectively. In turn, $\alpha$ and $\alpha^{\prime}$ are parameters that define the curve shape in the pre-peak and post-peak branch, respectively.

$$
\begin{gathered}
N=\sqrt{2 E_{\mathrm{f}} \cdot A_{\mathrm{f}} \cdot P_{\mathrm{f}} \cdot \int_{s_{\mathrm{f}}}^{s\left(x=\widetilde{L_{\mathrm{b}}}\right)} \tau(s) \cdot d s} \\
\tau(s)= \begin{cases}\tau_{\mathrm{m}} \cdot\left(\frac{s}{s_{\mathrm{m}}}\right)^{\alpha} & \text { if } s \leq s_{\mathrm{m}} \\
\tau_{\mathrm{m}} \cdot\left(\frac{s}{s_{\mathrm{m}}}\right)^{-\alpha^{\prime}} & \text { if } s>s_{\mathrm{m}}\end{cases}
\end{gathered}
$$


Soares, S.; Freitas, N.; Nepomuceno, E.; Pereira, E.; Sena-Cruz, J. (2020) “Assessment of GFRP bond behaviour for the design of sustainable reinforced seawater concrete structures” Construction \& Building Materials, 231, 117277 1-17.

DOI: $10.1016 /$ j.conbuildmat.2019.117277

\subsection{Analytical results}

As referred before, the bond laws $(\tau-s)$ of each series were calibrated with the average experimental pullout force versus loaded end slip curves. During the inverse analysis, the search for $\alpha$ and $\alpha$ ' was conducted within the interval ]0, 1], whereas for $\tau_{\mathrm{m}}$ and $s_{\mathrm{m}}$ no boundaries were fixed. For the longitudinal elasticity modulus of the GFRP rods, the average values obtained in the mechanical characterization were used (see Section 3, Table 4). For the geometrical properties, a cross-sectional area $\left(A_{\mathrm{f}}\right)$ of $50.27 \mathrm{~mm}^{2}$ and $113.10 \mathrm{~mm}^{2}$ were assumed for $\emptyset 8$ and $\varnothing 12$, respectively, whereas in terms of cross-sectional perimeter $\left(P_{\mathrm{f}}\right)$, values of $25.13 \mathrm{~mm}$ and $37.70 \mathrm{~mm}$ were assumed for $\varnothing 8$ and $\varnothing 12$, respectively.

Figure 12 presents the pullout force versus loaded end slip $\left(F-s_{1}\right)$ curves obtained by numerical inverse analysis procedure and the envelope of the experimental results. While observing Figure 12 it is possible to conclude that the developed numerical strategy was able to predict with good accuracy the $F$-s curves of all the experimental test series in the different phases that characterize the bond behaviour (pre-peak phase up to maximum pullout force and post-peak phase), regardless of the GFRP rod diameter used, the anchorage length adopted and the water type used in the concrete composition. Table 8 shows the values of the parameters defining the local bond law (see also Eq. (9)) which lead to the curves presented in Figure 12. Moreover, this table also includes the normalized errors of the numerical fitting procedure in terms of (i) ratio between the area between the experimental and numerical curves and the area under the experimental curve ( $\left.e_{\text {area }}\right)$, (ii) ratio between the maximum experimental pullout force and the corresponding numerical value $\left(e_{\text {Fmax }}\right)$ and (iii) ratio between the experimental loaded end slip at maximum pullout force and the corresponding numerical value $\left(e_{\text {slmax }}\right)$. In general, the obtained $e_{\text {area }}$ was very small. In terms of $e_{\mathrm{Fmax}}$ and $e_{\mathrm{s} \text { max }}$, the strategy adopted yielded to very good predictions (error values equal to zero).

To better understand the results obtained from the inverse analysis, particularly the influence of the studied variables (GFRP rod diameter, anchorage length and water type in the concrete composition) on the results, the bond laws obtained from the parameters presented in Table 8 were plotted and compared in Figure 13. Analysing the parameters of the local bond laws obtained, the following main conclusions can be pointed out: 
Soares, S.; Freitas, N.; Nepomuceno, E.; Pereira, E.; Sena-Cruz, J. (2020) “Assessment of GFRP bond behaviour for the design of sustainable reinforced seawater concrete structures” Construction \& Building Materials, 231, 117277 1-17.

DOI: 10.1016/j.conbuildmat.2019.117277

- $\quad$ The $s_{\mathrm{m}}$ value was mainly influenced by the $L_{\mathrm{b}}$ adopted and the water type used in the concrete composition. In general, for the series to which a $L_{b}=10 \varnothing$ was adopted instead of $L_{b}=5 \emptyset$, a $70 \%$ higher value of $s_{\mathrm{m}}$ was obtained. On the other hand, when SW was used instead of TW, an average decrease of $21 \%$ in $s_{\mathrm{m}}$ was verified;

- $\quad$ The $\tau_{\mathrm{m}}$ value was influenced by the GFRP rod diameter used, by the $L_{\mathrm{b}}$ adopted as well as the water type used in the concrete composition. In terms of GFRP rod diameter influence, when the $\emptyset 12$ was used instead of $\varnothing 8$, an average increase of $10 \%$ and $33 \%$ was obtained respectively for TW and SW series. In its turn, when a $L_{\mathrm{b}}=10 \emptyset$ was used instead of $L_{\mathrm{b}}=5 \varnothing$, an average decrease of $14 \%$ in $\tau_{\mathrm{m}}$ was obtained. In terms of water type used in the concrete composition, when SW was used instead of TW, an average decrease of $19 \%$ in $\tau_{\mathrm{m}}$ was obtained;

- $\quad$ The parameter that defines the curve shape in the pre-peak branch $(\alpha)$ obtained by the inverse analysis has varied very little for all test series, which means that the local bond stiffness in the pre-peak phase of the $\tau$-s relationship was practically coincident;

- $\quad$ The parameter that define the curve shape in the post-peak branch $\left(\alpha^{\prime}\right)$ obtained in the inverse analysis is very dependent on the failure mode experimentally observed. An example of this is the TW_28D_Ø8_Lb10Ø series in which the complete rupture of the GFRP ribs was observed (see Table 7 and Figure 8 (a) and (b)) and, consequently, the obtained $\alpha^{\prime}$ was nil. However, when the same failure mode was observed, the influence of the GFRP rod diameter adopted as well as the water type used in the concrete composition became more evident. The $\alpha^{\prime}$ value increased with the increasing of the GFRP rod diameter and when SW was used instead of TW;

- $\quad$ The local bond $\tau-s$ law used showed to be flexible enough to accurately simulate both SW and TW series of the direct pullout tests. Based on the analysis carried out, TW yields to higher local shear strength and residual shear stress than SW.

For a safe and economic design of concrete structures reinforced with GFRP rods, the anchorage length required to reach the maximum capacity of the composite material $\left(L_{\mathrm{b}, \mathrm{eff}}\right)$ should be determined considering the requirements imposed by ultimate limit state conditions. The $L_{b \text {,eff }}$ is understood to be the length beyond which further increments of the bonded length do not lead to bond strength increments due to the GFRP rod failure. Using the numerical model described in this section as well as the corresponding interface laws obtained by the numerical 
Soares, S.; Freitas, N.; Nepomuceno, E.; Pereira, E.; Sena-Cruz, J. (2020) “Assessment of GFRP bond behaviour for the design of sustainable reinforced seawater concrete structures” Construction \& Building Materials, 231, 117277 1-17.

DOI: 10.1016/j.conbuildmat.2019.117277

procedure, the maximum pullout force $\left(F_{\max }\right)$ of the reinforced system was iteratively calculated by increasing the $L_{\mathrm{b}}$ value and for each test serie. In this analysis, the average values of the $\tau-s$ law parameters obtained (see Table 8) were considered regardless of the anchorage length adopted in the direct pullout tests. It should be noted that this approach yields to conservative values of the anchorage length only when other phenomena are not considered and properly prevented by design, such as concrete splitting.

Figure 14 shows the relationship between $F_{\max }$ and $L_{\mathrm{b}}$ for each GFRP rod diameter and water type. This information can be useful for design purposes in terms of the determination of the required anchorage length for a certain maximum pullout force imposed at ultimate limit state condition. Analysing Figure 14, the following main conclusions can be pointed out:

- $\quad$ For $\varnothing 8$ GFRP rods (Figure $14(\mathrm{a}))$, a $L_{\mathrm{b}, \text { eff }}$ of $177 \mathrm{~mm}\left(L_{b}=22 \varnothing\right)$ and $315 \mathrm{~mm}\left(L_{b}=39 \emptyset\right)$ were obtained in the TW and SW series, respectively. According to the obtained results, it is not possible to increase de bond strength since the failure of the system occurred by tensile failure of the $\varnothing 8$ GFRP rod (the mechanical properties of the GFRP rods were determined in this work and were presented in Section 3 - see Table 4);

- $\quad$ For $\varnothing 12$ GFRP rods (Figure $14(\mathrm{~b}))$, a $L_{\mathrm{b}, \text { eff }}$ of $259 \mathrm{~mm}\left(L_{\mathrm{b}}=22 \varnothing\right)$ and $346 \mathrm{~mm}\left(L_{\mathrm{b}}=29 \varnothing\right)$ were obtained in the TW and SW series, respectively. Like in the previous case, tensile failure of the $\emptyset 12$ GFRP rod controlled the failure mode of the system;

- According to the results and comparing the influence of the water type used in the concrete composition, is remarkable that for the SW case is necessary a higher $L_{\mathrm{b}}$ to allow the full use of the tensile strength of the GFRP rods, in comparison to the use of TW.

\section{CONCLUSIONS}

The study presented in this paper particularly focussed on the bond behaviour characterization, considering its importance in the structural design. The research included two distinct phases: (i) development of high strength concrete compositions (with TW and SW) including characterization at fresh and hardened state and (ii) assessment of the bond behaviour between ComBAR® GFRP ribbed round rods and the developed concrete through an experimental program composed by 48 direct pullout tests in concrete cubic blocks strengthened with this specific type of GFRP rods. In both phases the effect of the use of SW instead TW in the concrete mixture 
Soares, S.; Freitas, N.; Nepomuceno, E.; Pereira, E.; Sena-Cruz, J. (2020) “Assessment of GFRP bond behaviour for the design of sustainable reinforced seawater concrete structures” Construction \& Building Materials, 231, 117277 1-17.

DOI: 10.1016/j.conbuildmat.2019.117277

was studied. In the second phase, the influence of concrete age (7 or 28 days), GFRP rod diameter used ( $\varnothing 8$ or $\varnothing 12)$ and anchorage length adopted (5Ø or $10 \varnothing)$ were also investigated. Additionally, based on the experimental research results, an analytical model capable of determining the local bond stress-slip law which governs the bond behaviour was used. This paper presented and analysed the obtained experimental and analytical results. In the present section the main conclusions of the research work are highlighted.

The procedure used to determine the concrete composition based on the modified expressions method proposed by Andreasen and Andersen proved to be adequate in the development and optimization of the solid component of the concrete matrix. The final concrete composition presented the good mechanical properties required in special projects, particularly in maritime environments such as adequate workability at fresh state and high mechanical strength at hardened state.

From the concrete characterization tests carried out, the following main conclusions can be pointed out:

- SW provided a higher cohesion, viscosity and compactness to the fresh concrete. Results have indicated also that SW reduced the concrete setting time and led to a faster development of its mechanical properties;

- The compression tests performed at 7 days of age showed that the concrete which included SW presented a higher value of compressive strength $(\approx+8 \%)$ than the TW concrete;

- The compression tests performed at 28 days of age showed that the concrete which included TW presented a higher value of compressive strength $(\approx+15 \%)$ and modulus of elasticity $(\approx+9 \%)$, than the SW concrete.

From the direct pullout test results, the following main conclusions can be highlighted:

- Three different failure modes were observed, mainly: (i) CR - debonding failure at the interface GFRP/concrete with complete rupture of GFRP ribs, (ii) PR - debonding failure at the interface GFRP/concrete with partial rupture of GFRP ribs and (iii) D - debonding failure (the most frequently observed). Thus, it was found that the bond mechanism between the GFRP rod and the concrete is not only frictional but also has a mechanical adhesion component conferred by the rod ribs; 
Soares, S.; Freitas, N.; Nepomuceno, E.; Pereira, E.; Sena-Cruz, J. (2020) “Assessment of GFRP bond behaviour for the design of sustainable reinforced seawater concrete structures” Construction \& Building Materials, 231, 117277 1-17.

DOI: 10.1016/j.conbuildmat.2019.117277

- The larger GFRP rod diameter provided the higher values of maximum pullout force $\left(F_{\max }\right)$ and shear strength $\left(\tau_{\max }\right)$. Additionally, higher values of loaded end slip $\left(s_{1}\right)$ and fracture energy $\left(G_{\mathrm{f}}\right)$ were also obtained;

- The longer anchorage length $\left(L_{\mathrm{b}}\right)$ provided an increase in $F_{\max }$. On the other hand, by increasing the $L_{\mathrm{b}}$, a larger contact surface between GFRP and concrete was mobilized and consequently lower $\tau_{\max }$ were obtained, due to the non-linear distribution of the bond stresses. Additionally, higher values of $s_{1}$ and $G_{\mathrm{f}}$ were obtained with the increase of $L_{\mathrm{b}}$;

- The use of SW instead of TW on the concrete mixture had some influence on the interface behaviour between GFRP and concrete. In the specimens where SW was included, a slightly lower values of normalized maximum pullout force $\left(\bar{F}_{\max }\right)$ and shear strength $\left(\bar{\tau}_{\max }\right)$ were obtained. Nevertheless, it can be concluded that the use of SW had no severe effects on the bond behaviour between the GFRP and concrete.

Using analytical modelling and inverse analysis, a local bond stress-slip $(\tau-s)$ relationship was obtained from the experimental test results. From the analysis carried out, the following considerations can be made:

- The adopted analytical model to obtain the local bond $\tau$-s law has shown a good performance on modelling the direct pullout tests and provided a better understanding of the bond behaviour between the GFRP rods and the concrete with different water type;

- $\quad$ The numerical strategy was able to predict with good accuracy the pullout force versus loaded end slip curves for all the experimental test series in the different phases that characterize the bond behaviour (prepeak phase up to maximum pullout force and post-peak phase), regardless of the GFRP rod diameter used, the anchorage length adopted, and the water type used in the concrete composition;

- $\quad$ The local bond $\tau$-s law used demonstrated enough flexibility to simulate both SW and TW series of the direct pullout tests. Based on the analysis carried out, TW yields to higher local shear strength and residual shear stress than SW;

- Based on the numerical procedure and for a safe and economic design of RC structures with GFRP rods, the anchorage length required to reach the maximum capacity of the GFRP rod $\left(L_{\mathrm{b}, \mathrm{eff}}\right)$ was determined. According to the results, the $L_{\mathrm{b}, \text { eff }}$ is $22 \varnothing$ for TW concrete and varies between $29 \emptyset-39 \varnothing$ for SW concrete. 
Soares, S.; Freitas, N.; Nepomuceno, E.; Pereira, E.; Sena-Cruz, J. (2020) “Assessment of GFRP bond behaviour for the design of sustainable reinforced seawater concrete structures” Construction \& Building Materials, 231, 117277 1-17.

DOI: $10.1016 /$ j.conbuildmat.2019.117277

Finally, the present study constitutes a first milestone for an extended research that aims to analyse the concrete made with seawater (SW) and the behaviour of RC structures with GFRP bars over time. Based on the obtained results, it can be said that the use of seawater does not yielded to short-term significant detrimental effects. Future studies should be done in order to assess the long-term effects and durability of the proposed system.

\section{ACKNOWLEDGEMENTS}

The study presented in this paper is a part of the research project "NEXT-SEA: Next Generation Monitoring of Coastal Systems in a Scenario of Global Change", financed by CCDRN and FEDER funds in the scope of the Next-sea project (NORTE-01-0145-FEDER-000032). The authors acknowledge all the companies that have been involved supporting and contributing for the development of this study, mainly: S\&P Clever Reinforcement Ibérica Lda., Burgoparaíso - Unipessoal Lda., Secil, Sika Portugal - Produtos Construção e Indústria S.A. The first and the last authors wishes also to acknowledge the grants SFRH/BD/131913/2017 and SFRH/BSAB/150266/2019, respectively, provided by FCT, financed by European Social Fund and by national funds through the FCT/MCTES.

\section{REFERENCES}

1. Rosegrant, M.W., X. Cai, and S.A. Cline, World water and food to 2025: dealing with scarcity. 2002, Washington, D.C.: International Food Policy Research Institute.

2. Shiklomanov, I.A., World water resources. A new appraisal and assessment for the 21st century, 1998.

3. Ercin, A.E. and A.Y. Hoekstra, Water footprint scenarios for 2050: A global analysis. Environment international, 2014. 64: p. 71-82.

4. Mekonnen, M.M. and A.Y. Hoekstra, Four billion people facing severe water scarcity. Science advances, 2016. 2(2): p. e1500323.

5. Xiao, J., et al., Use of sea-sand and seawater in concrete construction: Current status and future opportunities. Construction and Building Materials, 2017. 155: p. 1101-1111.

6. Wegian, F.M., Effect of seawater for mixing and curing on structural concrete. IES Journal Part A: Civil and Structural Engineering, 2010. 3(4): p. 235-243.

7. Shi, X., et al., Durability of steel reinforced concrete in chloride environments: An overview. Construction and Building Materials, 2012. 30: p. 125-138.

8. Ragab, A.M., et al., Evaluation of field concrete deterioration under real conditions of seawater attack. Construction and Building Materials, 2016. 119: p. 130-144.

9. Pradelle, S., M. Thiéry, and V. Baroghel-Bouny, Sensitivity analysis of chloride ingress models: Case of concretes immersed in seawater. Construction and Building Materials, 2017. 136: p. 44-56.

10. Maes, M., F. Mittermayr, and N. De Belie, The influence of sodium and magnesium sulphate on the penetration of chlorides in mortar. Materials and Structures/Materiaux et Constructions, 2017. 50(2).

11. Goldston, M., A. Remennikov, and M.N. Sheikh, Flexural behaviour of GFRP reinforced high strength and ultra high strength concrete beams. Construction and Building Materials, 2017. 131: p. 606-617.

12. Sena-Cruz, J.M., et al., Efficiency of different techniques in flexural strengthening of RC beams under monotonic and fatigue loading. Construction and Building Materials, 2012. 29: p. 175-182. 
Soares, S.; Freitas, N.; Nepomuceno, E.; Pereira, E.; Sena-Cruz, J. (2020) “Assessment of GFRP bond behaviour for the design of sustainable reinforced seawater concrete structures” Construction \& Building Materials, 231, $1172771-17$.

DOI: $10.1016 /$ j.conbuildmat.2019.117277

13. Micelli, F. and A. Nanni, Durability of FRP rods for concrete structures. Construction and Building Materials, 2004. 18(7): p. 491-503.

14. Monaldo, E., F. Nerilli, and G. Vairo, Basalt-based fiber-reinforced materials and structural applications in civil engineering. Composite Structures, 2019. 214: p. 246-263.

15. D'Antino, T. and M.A. Pisani, Long-term behavior of GFRP reinforcing bars. Composite Structures, 2019. 227.

16. Zhou, A., C.L. Chow, and D. Lau, Structural behavior of GFRP reinforced concrete columns under the influence of chloride at casting and service stages. Composites Part B: Engineering, 2018. 136: p. 1-9.

17. Robert, M. and B. Benmokrane, Combined effects of saline solution and moist concrete on long-term durability of GFRP reinforcing bars. Construction and Building Materials, 2013. 38: p. 274-284.

18. Ashrafi, H., et al., Effect of Sequential Exposure to UV Radiation and Water Vapor Condensation and Extreme Temperatures on the Mechanical Properties of GFRP Bars. Journal of Composites for Construction, 2018. 22(1).

19. Li, Y.L., et al., Experimental study on seawater and sea sand concrete filled GFRP and stainless steel tubular stub columns. Thin-Walled Structures, 2016. 106(Supplement C): p. 390-406.

20. Mohammed, T.U., H. Hamada, and T. Yamaji, Performance of seawater-mixed concrete in the tidal environment. Cement and Concrete Research, 2004. 34(4): p. 593-601.

21. Erniati, et al., Compressive strength and slump flow of self compacting concrete uses fresh water and sea water. ARPN Journal of Engineering and Applied Sciences, 2015. 10(6): p. 2373-2377.

22. Etxeberria, M., J.M. Fernandez, and J. Limeira, Secondary aggregates and seawater employment for sustainable concrete dyke blocks production: Case study. Construction and Building Materials, 2016. 113(Supplement C): p. 586-595.

23. Etxeberria, M., A. Gonzalez-Corominas, and P. Pardo, Influence of seawater and blast furnace cement employment on recycled aggregate concretes' properties. Construction and Building Materials, 2016. 115(Supplement C): p. 496-505.

24. Yan, F., Z. Lin, and M. Yang, Bond mechanism and bond strength of GFRP bars to concrete: A review. Composites Part B: Engineering, 2016. 98: p. 56-69.

25. Chen, Y., et al., Accelerated aging tests for evaluations of durability performance of FRP reinforcing bars for concrete structures. Composite Structures, 2007. 78(1): p. 101-111.

26. El Refai, A., F. Abed, and A. Altalmas, Bond durability of basalt fiber-reinforced polymer bars embedded in concrete under direct pullout conditions. Journal of Composites for Construction, 2015. 19(5).

27. Yan, F., et al., Experimental study on bond durability of glass fiber reinforced polymer bars in concrete exposed to harsh environmental agents: Freeze-thaw cycles and alkaline-saline solution. Composites Part B: Engineering, 2017. 116: p. 406-421.

28. Qu, W., X. Zhang, and H. Huang, Flexural behavior of concrete beams reinforced with hybrid (GFRP and steel) bars. Journal of Composites for Construction, 2009. 13(5): p. 350-359.

29. Barris, C., et al., An experimental study of the flexural behaviour of GFRP RC beams and comparison with prediction models. Composite Structures, 2009. 91(3): p. 286-295.

30. Maranan, G.B., et al., Evaluation of the flexural strength and serviceability of geopolymer concrete beams reinforced with glass-fibre-reinforced polymer (GFRP) bars. Engineering Structures, 2015. 101: p. 529541.

31. Barris, C., et al., Experimental study on crack width and crack spacing for Glass-FRP reinforced concrete beams. Engineering Structures, 2017. 131: p. 231-242.

32. Miàs, C., et al., Experimental study of immediate and time-dependent deflections of GFRP reinforced concrete beams. Composite Structures, 2013. 96: p. 279-285.

33. Pereira, J.E.M., Estruturas de betão reforçadas com materiais compósitos em ambiente marítimo e concebidas com água do mar, in Departamento de Engenharia Civil. 2017, Universidade do Minho. 
Soares, S.; Freitas, N.; Nepomuceno, E.; Pereira, E.; Sena-Cruz, J. (2020) “Assessment of GFRP bond behaviour for the design of sustainable reinforced seawater concrete structures” Construction \& Building Materials, 231, 117277 1-17.

DOI: $10.1016 /$ j.conbuildmat.2019.117277

34. Hunger, M. and H. Brouwers. Development of self-compacting eco-concrete. in Proceedings 16th Ibausil, International Conference on Building Materials (Internationale Baustofftagung), Weimar, FA FingerInstitut für Baustoffkunde, Weimar, Germany. 2006.

35. NP EN 197-1:2001 in Cimento - Parte 1: Composição, especificações e critérios de conformidade para cimentos correntes. Caparica (Portugal): IPQ - Instituto Português da Qualidade.

36. NP EN 933-1:2001, in Análise granulométrica. Método de peneiração - Parte 1: Ensaios das propriedades geométricas dos agregados. Caparica (Portugal): IPQ - Instituto Português da Qualidade.

37. NP EN 12350-8:2010, in Ensaios do betão fresco - Parte 8: Betão autocompactável, ensaio de espalhamento. Caparica (Portugal): IPQ - Instituto Português da Qualidade.

38. NP EN 12390-3:2011, in Testing hardened concrete. Part 3: Compressive strength of test specimens. Caparica (Portugal): IPQ - Instituto Português da Qualidade.

39. NP EN 1992-1-1:2010, in Eurocódigo 2 - Projeto de Estruturas de Betão. Parte 1: Regras gerais e regras para edifícios. Caparica (Portugal): IPQ - Instituto Português da Qualidade; 2010.

40. Antonov, J.I., Locarnini, R.A., Boyer, T.P., Mishonov, A.V., Garcia, H.E., World Ocean Atlas 2005 , Volume 2: Salinity. S. Levitus, Ed. NOAA Atlas NESDIS 62, U.S. Government Printing Office, Washington, D.C., 182 pp., 2006.

41. ASTM D7205/D7205M:2006, in Standard test method for tensile properties of fiber reinforced polymer matrix composite bars. American Society for Testing and Materials, Pennsylvania, USA.

42. $\quad$ LNEC E397:1993, in Betões - Determinação do módulo de elasticidade em compressão. Especificação LNEC, Portugal.

43. Achillides, Z. and K. Pilakoutas, Bond behavior of fiber reinforced polymer bars under direct pullout conditions. Journal of Composites for Construction, 2004. 8(2): p. 173-181.

44. Yoo, D.Y., et al., Local bond-slip response of GFRP rebar in ultra-high-performance fiber-reinforced concrete. Composite Structures, 2015. 120: p. 53-64.

45. Mazaheripour, H., et al., Experimental study on bond performance of GFRP bars in self-compacting steel fiber reinforced concrete. Composite Structures, 2013. 95: p. 202-212.

46. Sujivorakul, C., A. Waas, and A. Naaman, Pullout response of a smooth fiber with an end anchorage. Journal of Engineering Mechanics, 2000. 126(9): p. 986-993.

47. Banholzer, B., W. Brameshuber, and W. Jung, Analytical simulation of pull-out tests-the direct problem. Cement and Concrete Composites, 2005. 27(1): p. 93-101.

48. Sena-Cruz, J., et al., Bond behavior between glulam and GFRP's by pullout tests. Composites Part B: Engineering, 2012. 43(3): p. 1045-1055.

49. Cunha, V.M., J.A. Barros, and J.M. Sena-Cruz, Pullout behavior of steel fibers in self-compacting concrete. Journal of Materials in Civil Engineering, 2009. 22(1): p. 1-9.

50. Cruz, J.S. and J. Barros, Modeling of bond between near-surface mounted CFRP laminate strips and concrete. Computers \& Structures, 2004. 82(17-19): p. 1513-1521.

51. Sena-Cruz, J., Strengthening of concrete structures with near-surface mounted CFRP laminate strips, in Dept. of Civil Engineering, Ph.D. thesis. 2005, Univ. of Minho.

52. Sena Cruz, J.M., et al., Bond behavior of near-surface mounted CFRP laminate strips under monotonic and cyclic loading. Journal of Composites for Construction, 2006. 10(4): p. 295-303.

53. Sena-Cruz, J., et al. Modelling of bond between galvanized steel rebars and concrete. in Congreso de Métodos Numéricos en Ingeniería. 2009. Barcelona, Spain: CIMNE. 
Soares, S.; Freitas, N.; Nepomuceno, E.; Pereira, E.; Sena-Cruz, J. (2020) “Assessment of GFRP bond behaviour for the design of sustainable reinforced seawater concrete structures” Construction \& Building Materials, 231, 117277 1-17.

DOI: 10.1016/j.conbuildmat.2019.117277

\section{LIST OF TABLES}

Table 1 - Fresh state concrete properties obtained during the composition development phase.

Table 2 - Hardened state concrete properties obtained during the composition development phase.

Table 3 - Direct pullout tests program (three specimens per series).

Table 4 - GFRP rods mechanical characterization (average values).

Table 5 - Fresh state concrete properties.

Table 6 - Hardened state concrete properties (average values).

Table 7 - Main results obtained from the pullout tests (average values).

Table 8 - Local bond stress-slip relationship parameters obtained from inverse analysis of the direct pullout tests. 
Soares, S.; Freitas, N.; Nepomuceno, E.; Pereira, E.; Sena-Cruz, J. (2020) “Assessment of GFRP bond behaviour for the design of sustainable reinforced seawater concrete structures” Construction \& Building Materials, 231, 117277 1-17.

DOI: $10.1016 /$ j.conbuildmat.2019.117277

Table 1 - Fresh state concrete properties obtained during the composition development phase.

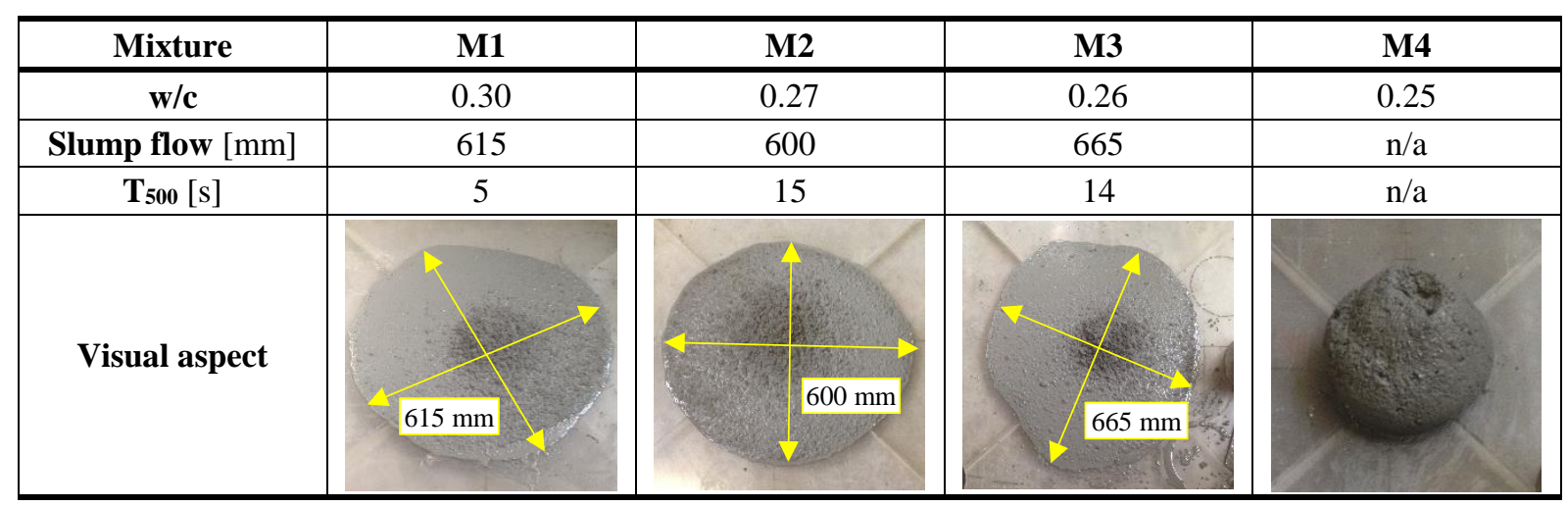

$\mathrm{n} / \mathrm{a}$ : result not available since the $500 \mathrm{~mm}$ was not reached.

Table 2 - Hardened state concrete properties obtained during the composition development phase.

\begin{tabular}{|c|c|c|c|c|}
\hline Mixture & M1 & M2 & M3 & M4 \\
\hline w/c & 0.30 & 0.27 & 0.26 & 0.25 \\
\hline$f_{\mathrm{cm}, 7}[\mathrm{MPa}]$ & $54.65(1.9 \%)$ & $54.60(2.8 \%)$ & $54.43(2.1 \%)$ & $57.87(1.4 \%)$ \\
\hline$f_{\mathrm{cm}, \mathbf{2 8}}[\mathrm{MPa}]$ & $66.80^{*}$ & $66.70^{*}$ & $66.50^{*}$ & $70.70^{*}$ \\
\hline
\end{tabular}

Note: the values in brackets are the coefficients of variation $(\mathrm{CoV}) ;{ }^{*}$ Estimated values according to NP EN 1992-1-1:2010 [39].

Table 3 - Direct pullout tests program (three specimens per series).

\begin{tabular}{|c|c|c|c|c|}
\hline Water type & $\begin{array}{c}\text { Age of concrete } \\
\text { [days] }\end{array}$ & $\begin{array}{c}\text { GFRP rod diameter } \\
{[\mathrm{mm}]}\end{array}$ & $\begin{array}{c}\text { Anchorage length } \\
{[\mathrm{mm}]}\end{array}$ & Designation \\
\hline \multirow{8}{*}{ TW } & \multirow{4}{*}{7} & \multirow{2}{*}{8} & 40 & TW_7D_ø8_Lb5Ø_i \\
\hline & & & 80 & TW_7D_Ø8_Lb10Ø_i \\
\hline & & \multirow{2}{*}{12} & 60 & TW_7D_Ø12_Lb5Ø_i \\
\hline & & & 120 & TW_7D_Ø12_Lb10Ø_i \\
\hline & \multirow{4}{*}{28} & \multirow{2}{*}{8} & 40 & TW_28D_Ø8_Lb5Ø_i \\
\hline & & & 80 & TW_28D_Ø8_Lb10Ø_i \\
\hline & & \multirow{2}{*}{12} & 60 & TW_28D_Ø12_Lb5Ø_i \\
\hline & & & 120 & TW_28D_Ø12_Lb10Ø_i \\
\hline \multirow{8}{*}{ SW } & \multirow{4}{*}{7} & \multirow{2}{*}{8} & 40 & SW_7D_Ø8_Lb5Ø_i \\
\hline & & & 80 & SW_7D_Ø8_Lb10Ø_i \\
\hline & & \multirow{2}{*}{12} & 60 & SW_7D_Ø12_Lb5Ø_i \\
\hline & & & 120 & SW_7D_Ø12_Lb10Ø_i \\
\hline & \multirow{4}{*}{28} & \multirow{2}{*}{8} & 40 & SW_28D_Ø8_Lb5Ø_i \\
\hline & & & 80 & SW_28D_Ø8_Lb10Ø_i \\
\hline & & \multirow{2}{*}{12} & 60 & SW_28D_Ø12_Lb5Ø_i \\
\hline & & & 120 & SW_28D_Ø12_Lb10Ø_i \\
\hline
\end{tabular}

Note: "i" represents the specimen 1,2 or 3. 
Soares, S.; Freitas, N.; Nepomuceno, E.; Pereira, E.; Sena-Cruz, J. (2020) “Assessment of GFRP bond behaviour for the design of sustainable reinforced seawater concrete structures” Construction \& Building Materials, 231, 117277 1-17.

DOI: $10.1016 /$ j.conbuildmat.2019.117277

Table 4 - GFRP rods mechanical characterization (average values).

\begin{tabular}{|c|c|c|c|c|}
\hline $\begin{array}{c}\text { GFRP rod } \\
\text { diameter }\end{array}$ & $\begin{array}{c}\boldsymbol{E}_{\mathbf{f}} \\
{[\mathrm{GPa}]}\end{array}$ & $\begin{array}{c}\boldsymbol{f}_{\text {ult }} \\
{[\mathrm{MPa}]}\end{array}$ & $\begin{array}{c}\boldsymbol{\varepsilon}_{\mathbf{f}} \\
{[\%]}\end{array}$ & Failure Mode \\
\hline $\boldsymbol{\varnothing 8}$ & $69.0(3.6 \%)$ & $1527.9(4.5 \%)$ & $1.8(0.1 \%)$ & Tensile Failure \\
\hline $\boldsymbol{\varnothing 1 2}$ & $70.1(3.1 \%)$ & $1447.1(6.5 \%)$ & $1.8(1.0 \%)$ & Tensile Failure \\
\hline
\end{tabular}

Note: the values in brackets are the coefficients of variation $(\mathrm{CoV})$.

Table 5 - Fresh state concrete properties.

\begin{tabular}{|c|c|c|c|c|c|c|c|c|}
\hline \multirow{2}{*}{ Concrete casting } & \multicolumn{2}{|c|}{ Concrete casting 1} & \multicolumn{2}{|c|}{ Concrete casting 2} & \multicolumn{2}{|c|}{ Concrete casting 3} & \multicolumn{2}{|c|}{ Concrete casting 4} \\
\hline & $1^{\text {st }}$ batch & $2^{\text {nd }}$ batch & $1^{\text {st }}$ batch & $2^{\text {nd }}$ batch & $1^{\text {st }}$ batch & $2^{\text {nd }}$ batch & $1^{\text {st }}$ batch & $2^{\text {nd }}$ batch \\
\hline Water type & TW & TW & SW & SW & SW & SW & TW & TW \\
\hline Slump flow $[\mathrm{mm}]$ & 625 & 613 & 421 & 448 & 330 & 400 & 400 & 485 \\
\hline $\mathbf{T}_{500}[\mathrm{~s}]$ & 13 & 15 & $\mathrm{n} / \mathrm{a}$ & $\mathrm{n} / \mathrm{a}$ & $\mathrm{n} / \mathrm{a}$ & $\mathrm{n} / \mathrm{a}$ & 16 & 15 \\
\hline Visual aspect & $625 \mathrm{~m}$ & & $421 \mathrm{n}$ & & & & & 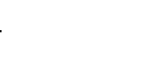 \\
\hline
\end{tabular}

n/a: result not available since the $500 \mathrm{~mm}$ was not reached.

Table 6 - Hardened state concrete properties (average values).

\begin{tabular}{|c|c|c|}
\hline $\begin{array}{c}\text { Compressive Strength }\left(f_{\mathrm{cm}}\right) \\
\text { and Modulus of Elasticity }\left(E_{\mathrm{cm}}\right)\end{array}$ & $\begin{array}{c}\text { Tap water } \\
(\mathrm{TW})\end{array}$ & $\begin{array}{c}\text { Seawater } \\
(\mathrm{SW})\end{array}$ \\
\hline $\boldsymbol{f}_{\mathrm{cm}, \mathbf{7 d}[\mathrm{MPa}]}$ & $50.5(1.8 \%)$ & $54.5(4.0 \%)$ \\
\hline $\boldsymbol{f}_{\mathrm{cm}, \mathbf{2 8 d}}[\mathrm{MPa}]$ & $66.5(0.9 \%)$ & $58.0(4.4 \%)$ \\
\hline $\boldsymbol{E}_{\mathbf{c m}, \mathbf{7 d}[\mathrm{GPa}]}$ & $34.2(6.9 \%)$ & $27.3(1.3 \%)$ \\
\hline $\boldsymbol{E}_{\mathbf{c m}, \mathbf{2 8 d}[\mathrm{GPa}]}$ & $36.3(2.6 \%)$ & $33.4(2.3 \%)$ \\
\hline
\end{tabular}

Note: the values in brackets are the coefficients of variation $(\mathrm{CoV})$. 
Soares, S.; Freitas, N.; Nepomuceno, E.; Pereira, E.; Sena-Cruz, J. (2020) "Assessment of GFRP bond behaviour for the design of sustainable reinforced seawater concrete structures" Construction \& Building Materials, 231, $1172771-17$.

DOI: $10.1016 /$ j.conbuildmat.2019.117277

Table 7 - Main results obtained from the pullout tests (average values).

\begin{tabular}{|c|c|c|c|c|c|c|c|c|c|c|c|}
\hline Serie & {$\left[\begin{array}{c}f_{\mathrm{cm}} \\
{[\mathrm{MPa}]}\end{array}\right]$} & $\begin{array}{l}\boldsymbol{F}_{\max } \\
{[\mathrm{kN}]}\end{array}$ & $\begin{array}{c}\text { Slmax } \\
{[\mathrm{mm}]}\end{array}$ & $\begin{array}{c}S_{\text {fmax }} \\
{[\mathrm{mm}]}\end{array}$ & $\begin{array}{c}\boldsymbol{\tau}_{\max } \\
{[\mathrm{MPa}]}\end{array}$ & $\begin{array}{c}\boldsymbol{F}_{\mathbf{r}} \\
{[\mathrm{kN}]}\end{array}$ & $\begin{array}{c}\boldsymbol{G}_{\mathbf{f}} \\
{[\mathrm{kN} \cdot \mathrm{mm}]}\end{array}$ & $\begin{array}{c}\boldsymbol{F}_{\mathbf{r}} / \boldsymbol{F}_{\max } \\
{[\%]}\end{array}$ & $\left|\begin{array}{l}\bar{F}_{\text {max }} \\
\overline{\boldsymbol{\tau}}_{\text {max }}\end{array}\right|$ & $\overline{\boldsymbol{G}}_{\mathbf{f}}$ & FM \\
\hline TW_7D_Ø8_Lb5Ø & 50.5 & $\begin{array}{c}14.5 \\
(3.4 \%)\end{array}$ & $\begin{array}{c}0.59 \\
(4.2 \%)\end{array}$ & $\begin{array}{c}0.3 \\
(9.8 \%)\end{array}$ & $\begin{array}{c}14.4 \\
(3.4 \%)\end{array}$ & $\begin{array}{c}3.2 \\
(4.0 \%)\end{array}$ & $\begin{array}{c}66.0 \\
(4.0 \%)\end{array}$ & $\begin{array}{c}22.2 \\
(7.4 \%)\end{array}$ & 4.0 & 1.8 & $D^{1,2,3}$ \\
\hline TW_7D_Ø8_Lb10Ø & 50.5 & $\begin{array}{c}22.4 \\
(1.6 \%) \\
\end{array}$ & $\begin{array}{c}0.95 \\
(4.1 \%) \\
\end{array}$ & $\begin{array}{c}0.27 \\
(16.8 \%)\end{array}$ & $\begin{array}{c}11.1 \\
(1.6 \%)\end{array}$ & $\begin{array}{c}6.1 \\
(4.1 \%)\end{array}$ & $\begin{array}{l}107.6 \\
(2.3 \%)\end{array}$ & $\begin{array}{c}27.3 \\
(2.6 \%)\end{array}$ & 3.0 & 1.5 & $\mathrm{D}^{1,2,3}$ \\
\hline TW_7D_Ø12_Lb5Ø & 50.5 & $\begin{array}{c}40.6 \\
(7.8 \%) \\
\end{array}$ & $\begin{array}{c}0.88 \\
(5.0 \%) \\
\end{array}$ & $\begin{array}{c}0.36 \\
(9.9 \%) \\
\end{array}$ & $\begin{array}{c}18.0 \\
(7.8 \%) \\
\end{array}$ & $\begin{array}{c}12.7 \\
(17.9 \%) \\
\end{array}$ & $\begin{array}{c}209.6 \\
(12.3 \%) \\
\end{array}$ & $\begin{array}{c}30.9 \\
(10.2 \%) \\
\end{array}$ & 4.9 & 2.5 & $\mathrm{D}^{1,2,3}$ \\
\hline TW_7D_Ø12_Lb10Ø & 50.5 & $\begin{array}{c}69.3 \\
(2.6 \%) \\
\end{array}$ & $\begin{array}{c}1.66 \\
(4.8 \%) \\
\end{array}$ & $\begin{array}{c}0.37 \\
(10.8 \%) \\
\end{array}$ & $\begin{array}{c}15.3 \\
(2.6 \%) \\
\end{array}$ & $\begin{array}{c}21.9 \\
(10.4 \%) \\
\end{array}$ & $\begin{array}{l}358.9 \\
(3.6 \%) \\
\end{array}$ & $\begin{array}{c}31.6 \\
(7.8 \%) \\
\end{array}$ & 4.2 & 2.2 & $\mathrm{D}^{1,2,3}$ \\
\hline TW_28D_Ø8_Lb5Ø & 66.5 & $\begin{array}{c}19.8 \\
(4.8 \%) \\
\end{array}$ & $\begin{array}{c}0.81 \\
(9.3 \%) \\
\end{array}$ & $\begin{array}{c}0.39 \\
(25.7 \%)\end{array}$ & $\begin{array}{c}19.7 \\
(4.8 \%) \\
\end{array}$ & $\begin{array}{c}7.5 \\
(40.4 \%)\end{array}$ & $\begin{array}{c}134.5 \\
(22.5 \%) \\
\end{array}$ & $\begin{array}{c}37.8 \\
(39.3 \%)\end{array}$ & 4.4 & 3.0 & $\begin{array}{c}\mathrm{PR}^{1,2} \\
\mathrm{CR}^{3}\end{array}$ \\
\hline TW_28D_Ø8_Lb10Ø & 66.5 & $\begin{array}{c}33.7 \\
(2.1 \%) \\
\end{array}$ & $\begin{array}{c}1.54 \\
(4.0 \%) \\
\end{array}$ & $\begin{array}{c}0.31 \\
(24.1 \%) \\
\end{array}$ & $\begin{array}{c}16.8 \\
(2.1 \%) \\
\end{array}$ & $\begin{array}{c}33.5 \\
(4.6 \%) \\
\end{array}$ & $\begin{array}{l}329.2 \\
(4.3 \%) \\
\end{array}$ & $\begin{array}{c}99.5 \\
(6.2 \%) \\
\end{array}$ & 3.7 & 3.6 & $\mathrm{CR}^{1,2,3}$ \\
\hline TW_28D_Ø12_Lb5Ø & 66.5 & $\begin{array}{c}48.9 \\
(5.8 \%) \\
\end{array}$ & $\begin{array}{c}0.89 \\
(11.0 \%) \\
\end{array}$ & $\begin{array}{c}0.24 \\
(31.9 \%) \\
\end{array}$ & $\begin{array}{c}21.6 \\
(5.8 \%) \\
\end{array}$ & $\begin{array}{c}26.6 \\
(28.8 \%) \\
\end{array}$ & $\begin{array}{c}327.0 \\
(12.3 \%) \\
\end{array}$ & $\begin{array}{c}55.1 \\
(32.8 \%) \\
\end{array}$ & 4.8 & 3.2 & $\begin{array}{c}\mathrm{D}^{1} \\
\mathrm{CR}^{2,3} \\
\end{array}$ \\
\hline & 66.5 & $\begin{array}{c}81.8 \\
(2.5 \%) \\
\end{array}$ & $\begin{array}{c}1.91 \\
(3.6 \%) \\
\end{array}$ & $\begin{array}{c}0.32 \\
(10.2 \%) \\
\end{array}$ & $\begin{array}{c}18.1 \\
(2.5 \%) \\
\end{array}$ & $\begin{array}{c}38.7 \\
(18.7 \%) \\
\end{array}$ & $\begin{array}{l}504.9 \\
(9.0 \%) \\
\end{array}$ & $\begin{array}{c}47.2 \\
(16.9 \%) \\
\end{array}$ & 4.0 & 2.5 & $\mathrm{D}^{1,2,3}$ \\
\hline SW_7D_Ø8_Lb5Ø & 54.5 & $\begin{array}{c}12.2 \\
(10.6 \%)\end{array}$ & $\begin{array}{c}0.58 \\
(5.7 \%) \\
\end{array}$ & $\begin{array}{c}0.28 \\
(9.5 \%) \\
\end{array}$ & $\begin{array}{c}12.2 \\
(10.6 \%)\end{array}$ & $\begin{array}{c}2.7 \\
(16.4 \%) \\
\end{array}$ & $\begin{array}{c}51.2 \\
(6.0 \%) \\
\end{array}$ & $\begin{array}{c}22.0 \\
(9.2 \%) \\
\end{array}$ & 3.1 & 1.3 & $\mathrm{D}^{1,2,3}$ \\
\hline SW_7D_Ø8_Lb10Ø & 54.5 & $\begin{array}{c}22.6 \\
(5.9 \%) \\
\end{array}$ & $\begin{array}{c}1.01 \\
(6.7 \%) \\
\end{array}$ & $\begin{array}{c}0.30 \\
(10.2 \%) \\
\end{array}$ & $\begin{array}{c}11.3 \\
(5.9 \%) \\
\end{array}$ & $\begin{array}{c}7.3 \\
(13.8 \%) \\
\end{array}$ & $\begin{array}{l}118.3 \\
(4.1 \%) \\
\end{array}$ & $\begin{array}{c}32.2 \\
(8.7 \%) \\
\end{array}$ & 2.9 & 1.5 & $\mathrm{D}^{1,2,3}$ \\
\hline SW_7D_Ø12_Lb5Ø & 54.5 & $\begin{array}{c}39.9 \\
(3.5 \%) \\
\end{array}$ & $\begin{array}{c}0.91 \\
(4.9 \%)\end{array}$ & $\begin{array}{c}0.38 \\
(15.4 \%) \\
\end{array}$ & $\begin{array}{c}17.6 \\
(3.5 \%) \\
\end{array}$ & $\begin{array}{c}8.5 \\
(4.7 \%) \\
\end{array}$ & $\begin{array}{l}165.2 \\
(4.0 \%)\end{array}$ & $\begin{array}{c}21.4 \\
(5.9 \%) \\
\end{array}$ & 4.5 & 1.9 & $\mathrm{D}^{1,2,3}$ \\
\hline SW_7D_Ø12_Lb10Ø & 54.5 & $\begin{array}{c}71.0 \\
(5.6 \%) \\
\end{array}$ & $\begin{array}{c}1.66 \\
(3.9 \%) \\
\end{array}$ & $\begin{array}{c}0.53 \\
(40.1 \%) \\
\end{array}$ & $\begin{array}{c}15.7 \\
(5.6 \%) \\
\end{array}$ & $\begin{array}{c}24.7 \\
(15.0 \%)\end{array}$ & $\begin{array}{c}394.4 \\
(12.8 \%) \\
\end{array}$ & $\begin{array}{c}34.7 \\
(10.8 \%) \\
\end{array}$ & 4.0 & 2.2 & $\mathrm{D}^{1,2,3}$ \\
\hline SW_28D_Ø8_Lb5Ø & 58.0 & $\begin{array}{c}13.6 \\
(2.4 \%) \\
\end{array}$ & $\begin{array}{c}0.54 \\
(3.9 \%) \\
\end{array}$ & $\begin{array}{c}0.25 \\
(4.9 \%) \\
\end{array}$ & $\begin{array}{c}13.6 \\
(2.4 \%) \\
\end{array}$ & $\begin{array}{c}3.2 \\
(23.9 \%) \\
\end{array}$ & $\begin{array}{c}60.3 \\
(14.6 \%) \\
\end{array}$ & $\begin{array}{c}23.4 \\
(22.7 \%) \\
\end{array}$ & 3.3 & 1.5 & $\mathrm{D}^{1,2,3}$ \\
\hline SW_28D_Ø8_Lb10Ø & 58.0 & $\begin{array}{c}25.6 \\
(3.3 \%) \\
\end{array}$ & $\begin{array}{c}1.08 \\
(7.0 \%) \\
\end{array}$ & $\begin{array}{c}0.29 \\
(8.2 \%) \\
\end{array}$ & $\begin{array}{c}12.7 \\
(3.3 \%) \\
\end{array}$ & $\begin{array}{c}10.6 \\
(10.8 \%) \\
\end{array}$ & $\begin{array}{l}154.4 \\
(9.5 \%) \\
\end{array}$ & $\begin{array}{c}41.2 \\
(10.1 \%) \\
\end{array}$ & 3.1 & 1.9 & $\mathrm{D}^{1,2,3}$ \\
\hline SW_28D_Ø12_Lb5Ø & 58.0 & $\begin{array}{c}45.1 \\
(2.2 \%)\end{array}$ & $\begin{array}{c}0.81 \\
(6.5 \%)\end{array}$ & $\begin{array}{c}0.33 \\
(15.6 \%)\end{array}$ & $\begin{array}{c}19.9 \\
(2.2 \%)\end{array}$ & $\begin{array}{c}11.5 \\
(10.1 \%)\end{array}$ & $\begin{array}{l}209.9 \\
(3.9 \%)\end{array}$ & $\begin{array}{c}25.5 \\
(11.6 \%)\end{array}$ & 4.9 & 2.3 & $\mathrm{D}^{1,2,3}$ \\
\hline SW_28D_Ø12_Lb10Ø & 58.0 & $\begin{array}{c}68.7 \\
(6.9 \%)\end{array}$ & $\begin{array}{c}1.48 \\
(7.2 \%)\end{array}$ & $\begin{array}{c}0.32 \\
(5.8 \%)\end{array}$ & $\begin{array}{c}15.2 \\
(6.9 \%)\end{array}$ & $\begin{array}{c}22.9 \\
(8.0 \%)\end{array}$ & $\begin{array}{l}355.5 \\
(3.6 \%)\end{array}$ & $\begin{array}{c}33.3 \\
(6.0 \%)\end{array}$ & 3.7 & 1.9 & $\mathrm{D}^{1,2,3}$ \\
\hline
\end{tabular}

Notes: the values in brackets are the coefficients of variation $(\mathrm{CoV})$; FM - Failure Modes: CR - debonding failure at the interface GFRP/concrete + complete rupture of GFRP ribs; PR - debonding failure at the interface GFRP/concrete + partial rupture of GFRP ribs; D - debonding failure at the interface GFRP/concrete; 1,2,3 is the specimen number. 
Soares, S.; Freitas, N.; Nepomuceno, E.; Pereira, E.; Sena-Cruz, J. (2020) “Assessment of GFRP bond behaviour for the design of sustainable reinforced seawater concrete structures” Construction \& Building Materials, 231, 117277 1-17.

DOI: 10.1016/j.conbuildmat.2019.117277

Table 8 - Local bond stress-slip relationship parameters obtained from inverse analysis of the direct pullout tests.

\begin{tabular}{|c|c|c|c|c|c|c|c|}
\hline Series & $\begin{array}{c}\boldsymbol{S}_{\mathbf{m}} \\
{[\mathrm{mm}]}\end{array}$ & $\begin{array}{c}\boldsymbol{\tau}_{\mathbf{m}} \\
{[\mathrm{MPa}]}\end{array}$ & $\alpha$ & $\alpha^{\prime}$ & $\begin{array}{c}\boldsymbol{e}_{\text {area }} \\
{[\%]}\end{array}$ & $\begin{array}{c}\boldsymbol{e}_{\text {sImax }} \\
{[\%]}\end{array}$ & $\begin{array}{c}\boldsymbol{e}_{\mathrm{Fmax}} \\
{[\%]}\end{array}$ \\
\hline TW_28D_Ø8_Lb5Ø & 0.64 & 19.57 & 0.46 & 0.22 & 12.1 & 0.0 & 0.0 \\
\hline TW_28D_Ø8_Lb10Ø & 1.18 & 16.88 & 0.46 & 0.00 & 2.0 & 0.0 & 0.0 \\
\hline Average & 0.91 & 18.23 & 0.46 & 0.11 & - & - & - \\
\hline TW_28D_Ø12_Lb5Ø & 0.74 & 21.02 & 0.64 & 0.24 & 4.7 & 0.0 & 0.0 \\
\hline TW_28D_Ø12_Lb10Ø & 1.29 & 19.00 & 0.54 & 0.44 & 3.9 & 0.0 & 0.0 \\
\hline Average & 1.02 & 20.01 & 0.59 & 0.34 & - & - & - \\
\hline SW_28D_Ø8_Lb5Ø & 0.49 & 13.77 & 0.46 & 0.44 & 13.5 & 0.0 & 0.0 \\
\hline SW_28D_Ø8_Lb10Ø & 0.84 & 13.10 & 0.49 & 0.36 & 10.2 & 0.0 & 0.0 \\
\hline Average & 0.67 & 13.44 & 0.48 & 0.40 & - & - & - \\
\hline SW_28D_Ø12_Lb5Ø & 0.68 & 20.47 & 0.43 & 0.52 & 9.2 & 0.0 & 0.0 \\
\hline SW_28D_Ø12_Lb10Ø & 1.01 & 15.32 & 0.44 & 0.52 & 6.3 & 0.0 & 0.0 \\
\hline Average & 0.85 & 17.90 & 0.44 & 0.52 & - & - & - \\
\hline
\end{tabular}


Soares, S.; Freitas, N.; Nepomuceno, E.; Pereira, E.; Sena-Cruz, J. (2020) “Assessment of GFRP bond behaviour for the design of sustainable reinforced seawater concrete structures” Construction \& Building Materials, 231, 117277 1-17.

DOI: 10.1016/j.conbuildmat.2019.117277

\section{LIST OF FIGURES}

Figure 1 - Aggregates used in the concrete production: (a) sand; (b) gravel 4-8; (c) gravel 8-16.

Figure 2 - Granulometric analysis: (a) sieve analysis of the used aggregates; (b) mixture curve versus reference curve.

Figure 3 - Different anchorage lengths adopted: (1) 40, (2) 60, (3) 80 and (4) $120 \mathrm{~mm}$.

Figure 4 - Experimental set-up and instrumentation: (a) scheme; (b) photo. Note: dimensions in [mm].

Figure 5 - GFRP rods mechanical characterization: (a) test set-up; (b) typical failure mode observed.

Figure 6 - Concrete mechanical properties: (a) compressive strength; (b) modulus of elasticity.

Figure 7 - Pullout force versus loaded end slip curves obtained in all test series.

Figure 8 - Failure modes: (a) (b) CR - debonding failure + complete rupture of GFRP ribs (TW_28D_Ø8_Lb10Ø_1 and TW_28D_Ø8_Lb5Ø_3, respectively); (c) PR - debonding failure + partial rupture of GFRP ribs (TW_28D_Ø12_Lb10Ø_2); (d) D - debonding failure (TW_7D_ø8_Lb10Ø_2).

Figure 9 - Influence of the studied parameters: (a) maximum experimental pullout force; (b) experimental average shear strength; (c) experimental fracture energy; (d) Fr/Fmax ratio; (e) normalized maximum pullout force or normalized average shear strength; (f) normalized fracture energy. Note: the values in brackets represent the percentage increase when $\varnothing 12$ was used instead of $\varnothing 8$ (a-d) and when TW was used instead of SW (e-f).

Figure 10 - (a) Equilibrium of the GFRP rod; (b) Stress and strains in the materials surrounding the bond region.

Figure 11 - Entities in the analytical model [51].

Figure 12 - Pullout force versus loaded end slip curves obtained by inverse analysis of all the test series.

Figure 13 - Comparison of the local bond laws obtained in the inverse analysis.

Figure 14 - Maximum pullout force versus anchorage length for GFRP rods of (a) $\varnothing 8$ and (b) $\varnothing 12$. 
Soares, S.; Freitas, N.; Nepomuceno, E.; Pereira, E.; Sena-Cruz, J. (2020) "Assessment of GFRP bond behaviour for the design of sustainable reinforced seawater concrete structures" Construction \& Building Materials, 231, $1172771-17$.

DOI: $10.1016 / j$.conbuildmat.2019.117277

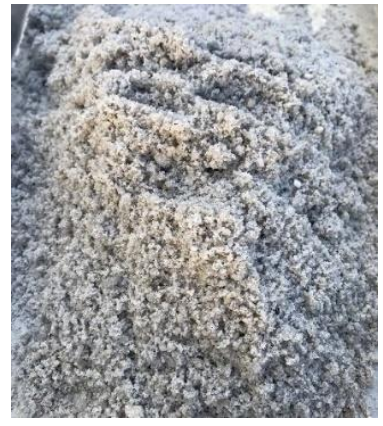

(a)

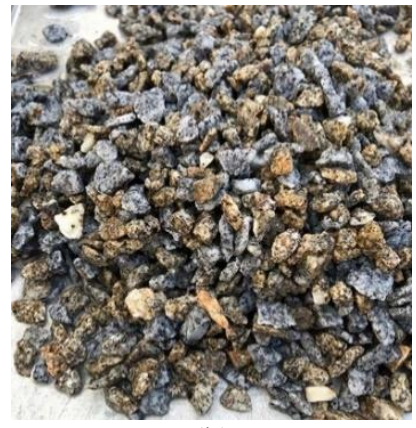

(b)

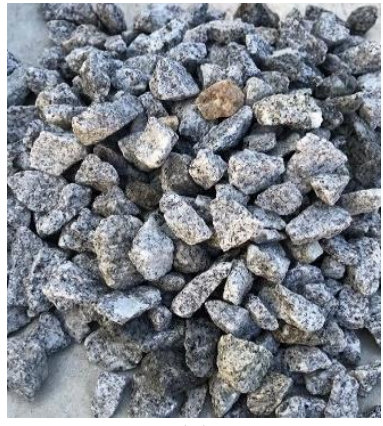

(c)

Figure 1 - Aggregates used in the concrete production: (a) sand; (b) gravel 4-8; (c) gravel 8-16.

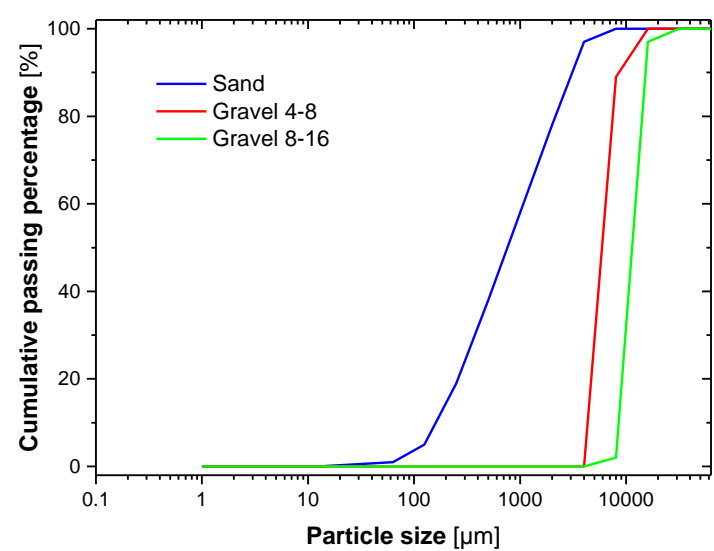

(a)

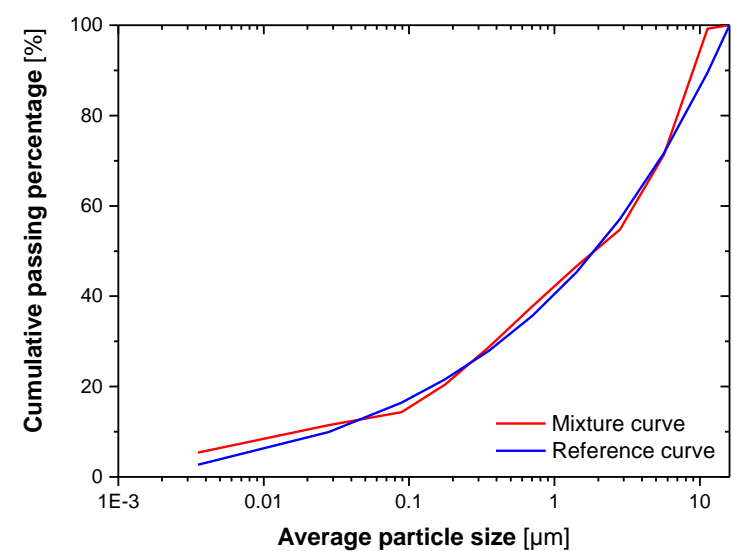

(b)

Figure 2 - Granulometric analysis: (a) sieve analysis of the used aggregates; (b) mixture curve versus reference curve.

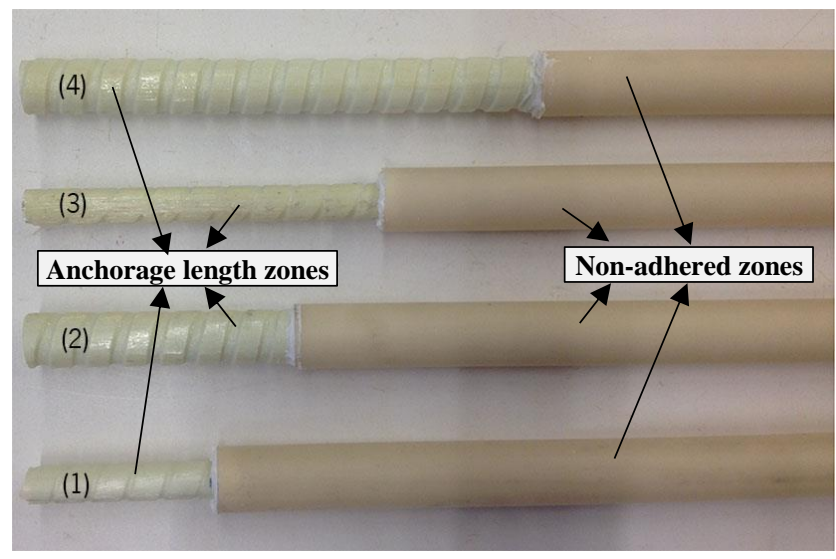

Figure 3 - Different anchorage lengths adopted: (1) 40, (2) 60, (3) 80 and (4) $120 \mathrm{~mm}$. 
Soares, S.; Freitas, N.; Nepomuceno, E.; Pereira, E.; Sena-Cruz, J. (2020) “Assessment of GFRP bond behaviour for the design of sustainable reinforced seawater concrete structures” Construction \& Building Materials, 231, 117277 1-17.

DOI: $10.1016 /$ j.conbuildmat.2019.117277
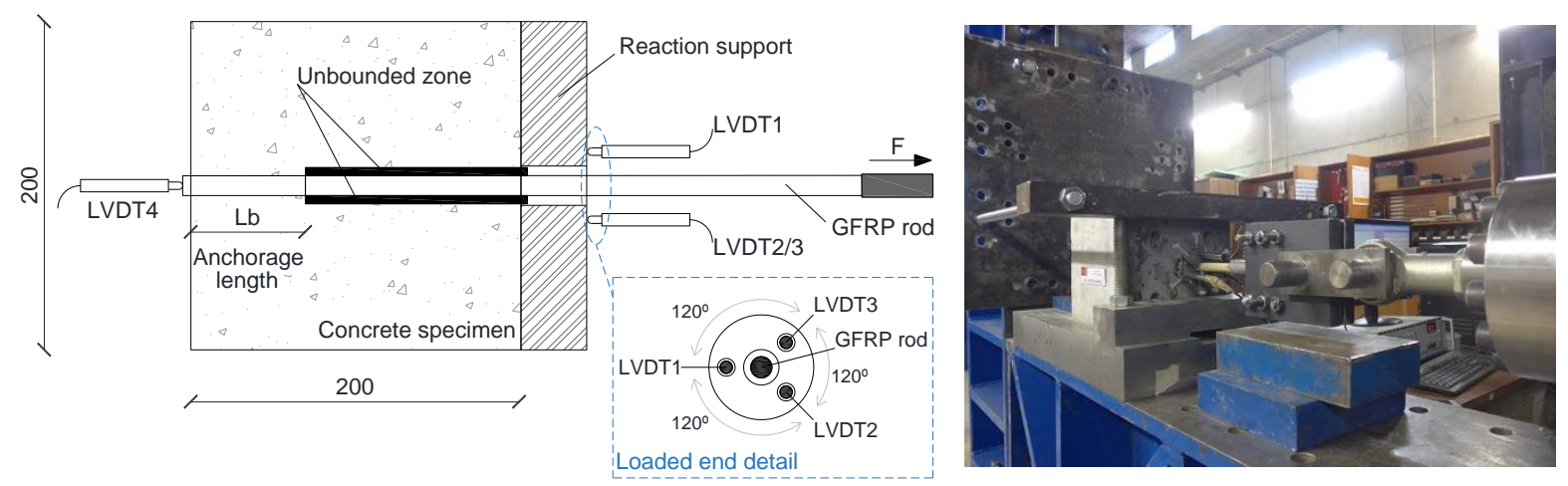

Figure 4 - Experimental set-up and instrumentation: (a) scheme; (b) photo. Note: dimensions in [mm].

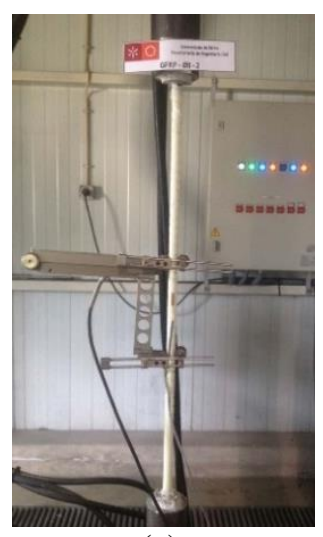

(a)

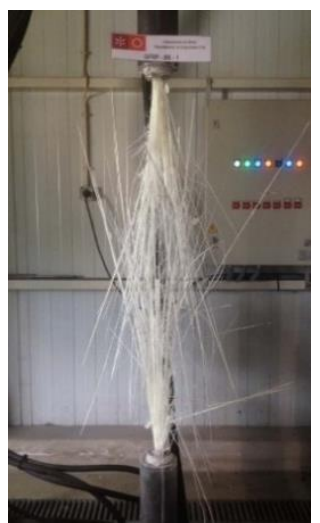

(b)

Figure 5 - GFRP rods mechanical characterization: (a) test set-up; (b) typical failure mode observed.

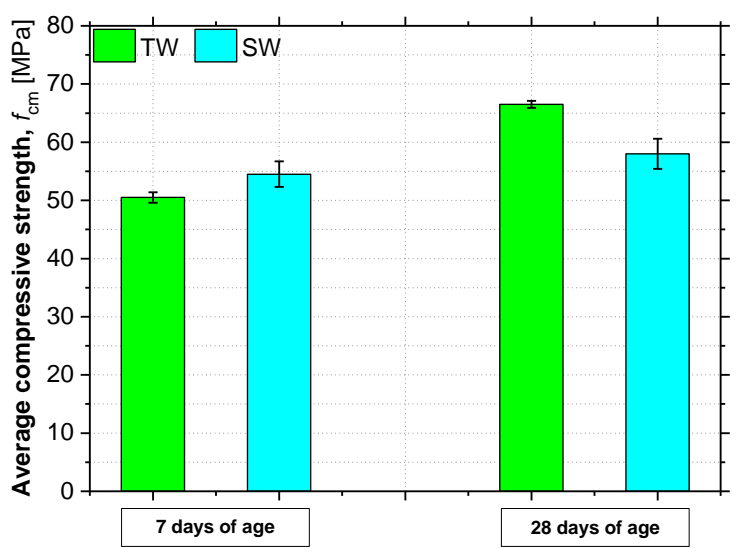

(a)

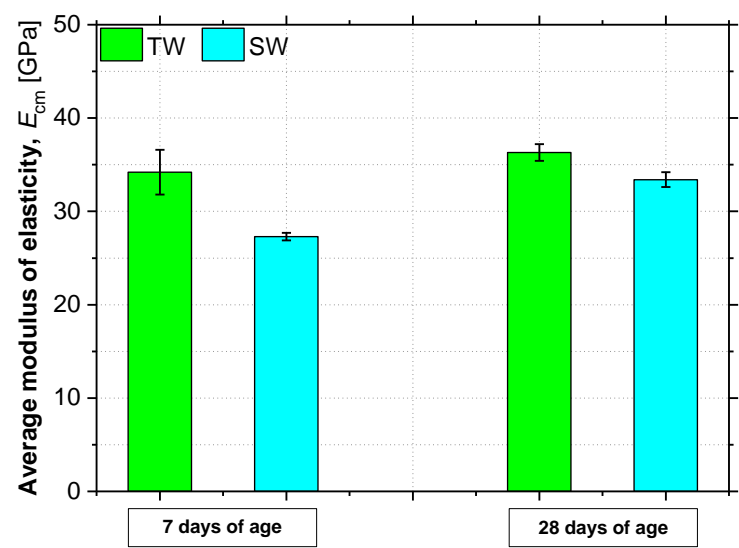

(b)

Figure 6 - Concrete mechanical properties: (a) compressive strength; (b) modulus of elasticity. 
Soares, S.; Freitas, N.; Nepomuceno, E.; Pereira, E.; Sena-Cruz, J. (2020) “Assessment of GFRP bond behaviour for the design of sustainable reinforced seawater concrete structures” Construction \& Building Materials, 231, 117277 1-17.

DOI: 10.1016/j.conbuildmat.2019.117277
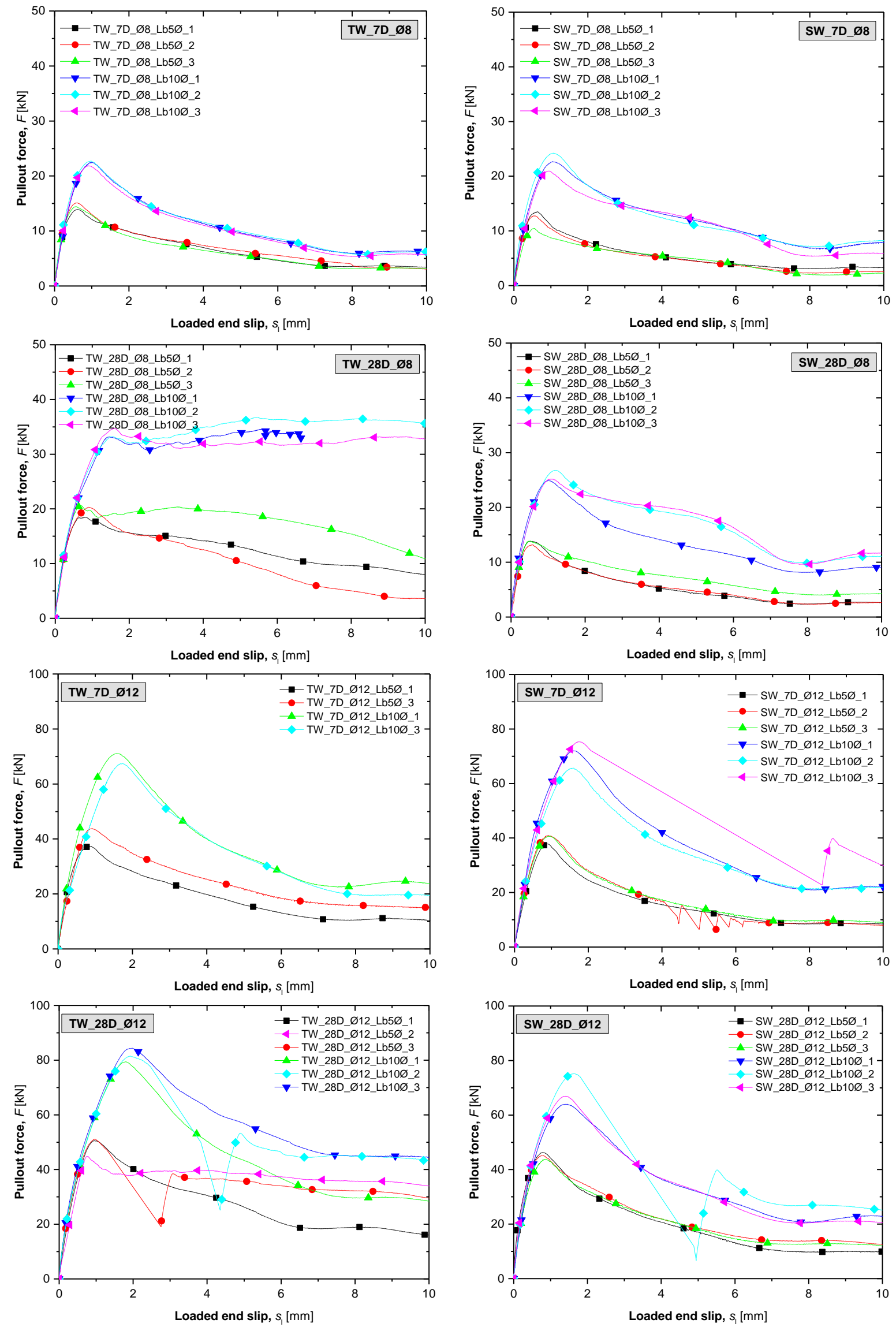

Figure 7 - Pullout force versus loaded end slip curves obtained in all test series. 
Soares, S.; Freitas, N.; Nepomuceno, E.; Pereira, E.; Sena-Cruz, J. (2020) “Assessment of GFRP bond behaviour for the design of sustainable reinforced seawater concrete structures” Construction \& Building Materials, 231, 117277 1-17.

DOI: 10.1016/j.conbuildmat.2019.117277

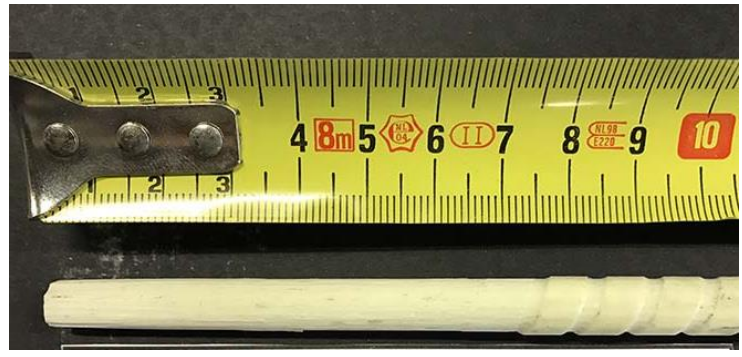

(a)

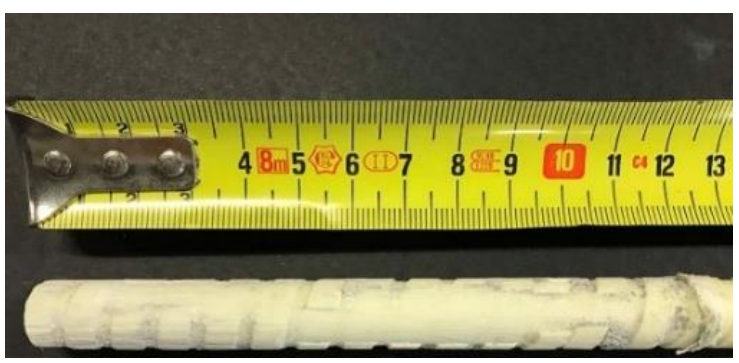

(c)

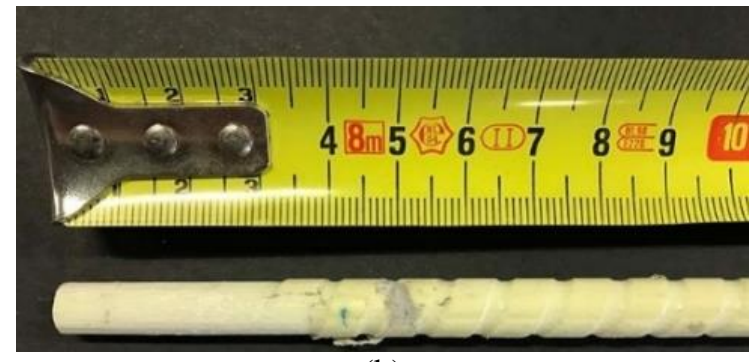

(b)

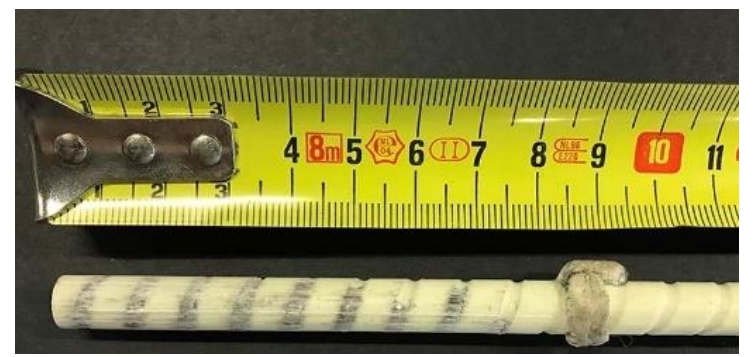

(d)

Figure 8 - Failure modes: (a) (b) CR - debonding failure + complete rupture of GFRP ribs (TW_28D_Ø8_Lb10Ø_1 and TW_28D_Ø8_Lb5Ø_3, respectively); (c) PR - debonding failure + partial rupture of GFRP ribs (TW_28D_Ø12_Lb10Ø_2); (d) D - debonding failure (TW_7D_ø8_Lb10Ø_2). 
Soares, S.; Freitas, N.; Nepomuceno, E.; Pereira, E.; Sena-Cruz, J. (2020) “Assessment of GFRP bond behaviour for the design of sustainable reinforced seawater concrete structures” Construction \& Building Materials, 231, $1172771-17$.

DOI: 10.1016/j.conbuildmat.2019.117277

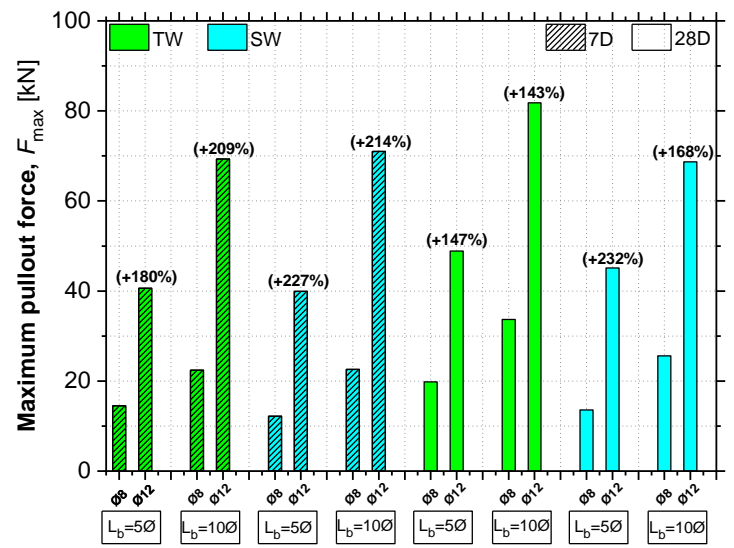

(a)

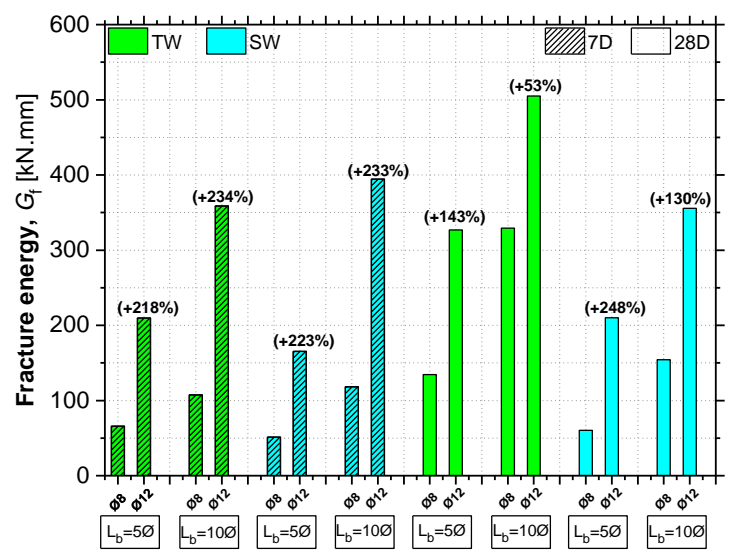

(c)

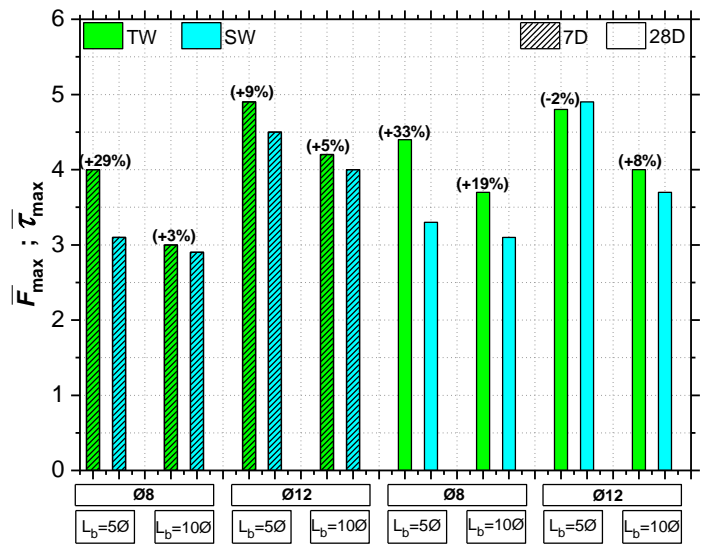

(e)

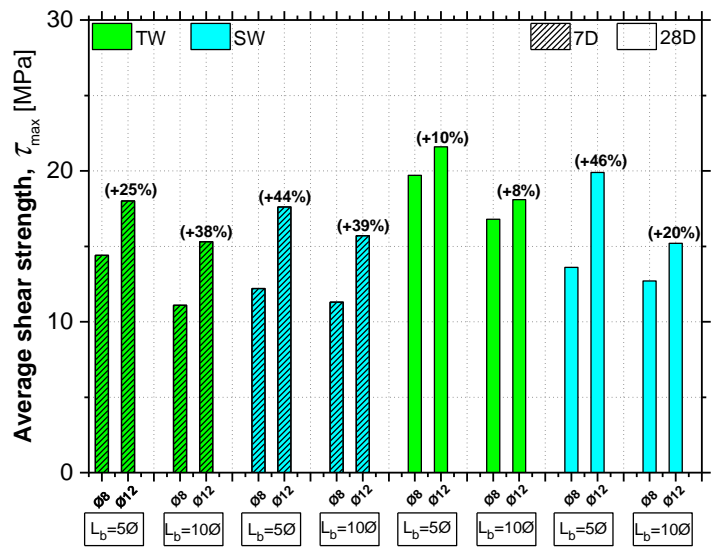

(b)

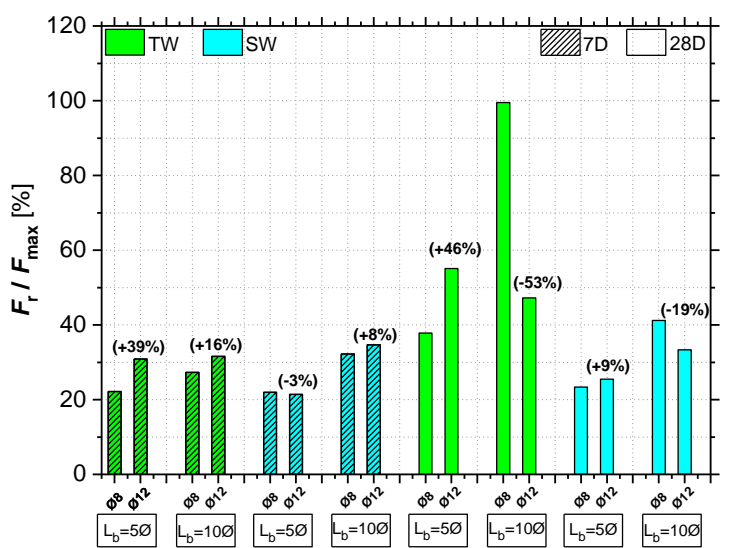

(d)

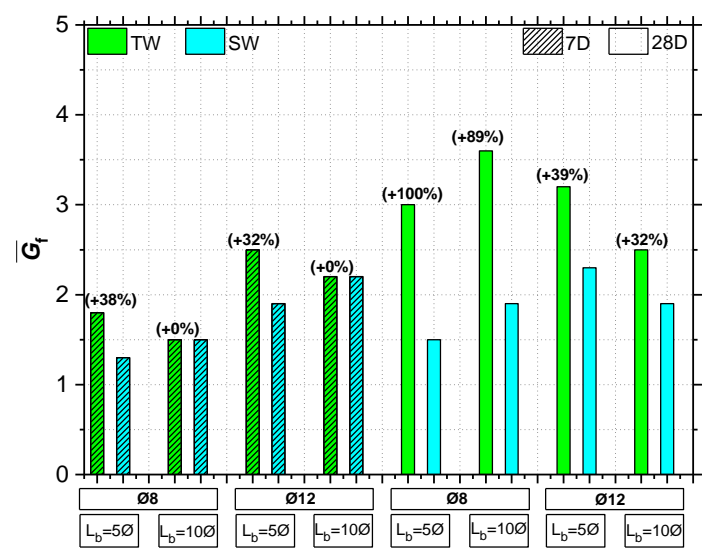

(f)

Figure 9 - Influence of the studied parameters: (a) maximum experimental pullout force; (b) experimental average shear strength; (c) experimental fracture energy; (d) $F_{\mathrm{r}} / F_{\max }$ ratio; (e) normalized maximum pullout force or normalized average shear strength; (f) normalized fracture energy. Note: the values in brackets represent the percentage increase when $\varnothing 12$ was used instead of $\varnothing 8$ (a-d) and when TW was used instead of SW (e-f). 
Soares, S.; Freitas, N.; Nepomuceno, E.; Pereira, E.; Sena-Cruz, J. (2020) “Assessment of GFRP bond behaviour for the design of sustainable reinforced seawater concrete structures” Construction \& Building Materials, 231, 117277 1-17.

DOI: 10.1016/j.conbuildmat.2019.117277

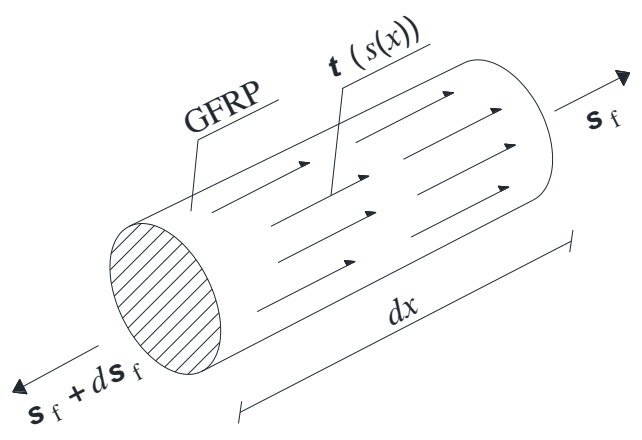

(a)

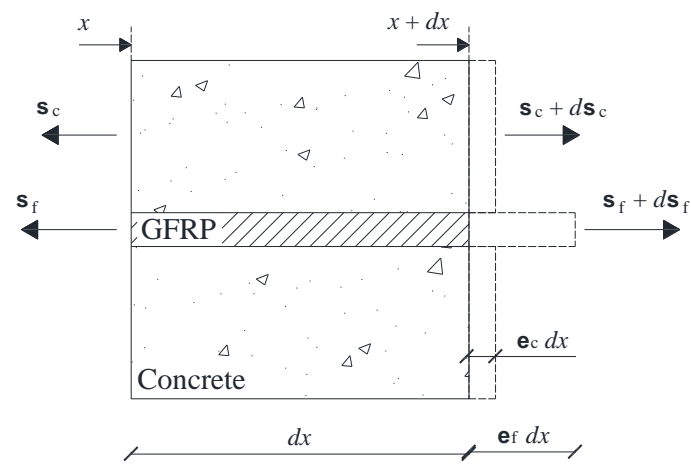

(b)

Figure 10 - (a) Equilibrium of the GFRP rod; (b) Stress and strains in the materials surrounding the bond region.

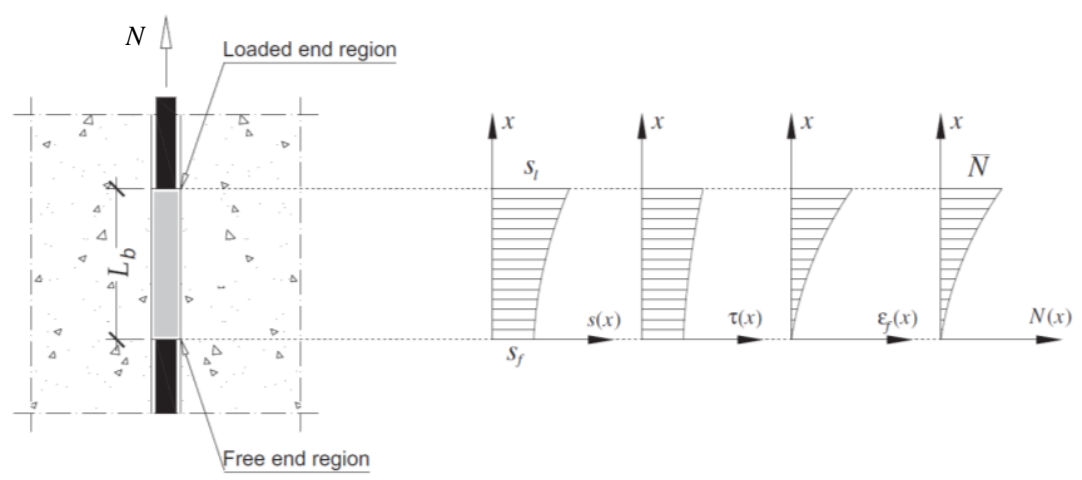

Figure 11 - Entities in the analytical model [51]. 
Soares, S.; Freitas, N.; Nepomuceno, E.; Pereira, E.; Sena-Cruz, J. (2020) “Assessment of GFRP bond behaviour for the design of sustainable reinforced seawater concrete structures” Construction \& Building Materials, 231, 117277 1-17.

DOI: 10.1016/j.conbuildmat.2019.117277
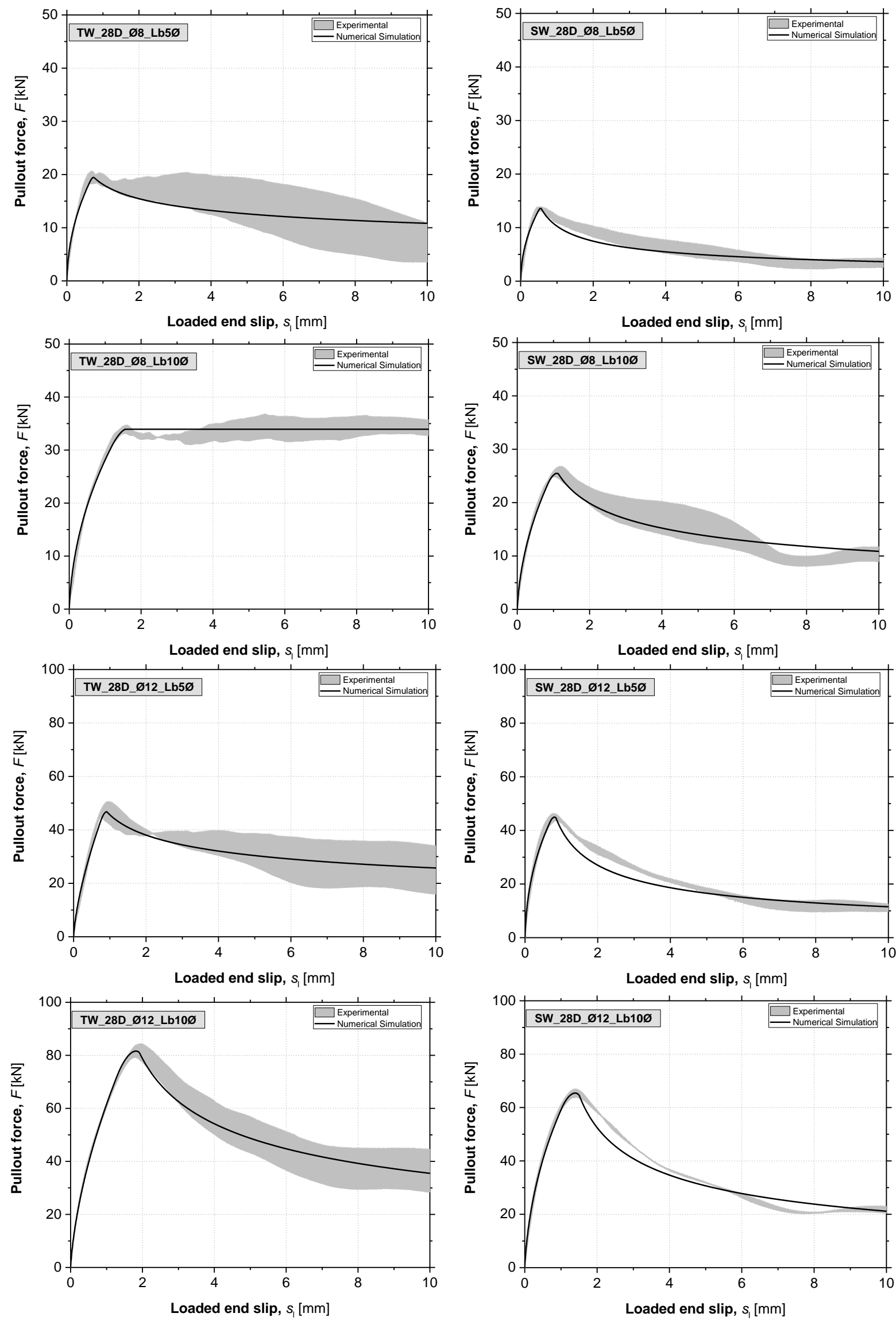

Figure 12 - Pullout force versus loaded end slip curves obtained by inverse analysis of all the test series. 
Soares, S.; Freitas, N.; Nepomuceno, E.; Pereira, E.; Sena-Cruz, J. (2020) “Assessment of GFRP bond behaviour for the design of sustainable reinforced seawater concrete structures” Construction \& Building Materials, 231, 117277 1-17.

DOI: $10.1016 /$ j.conbuildmat.2019.117277
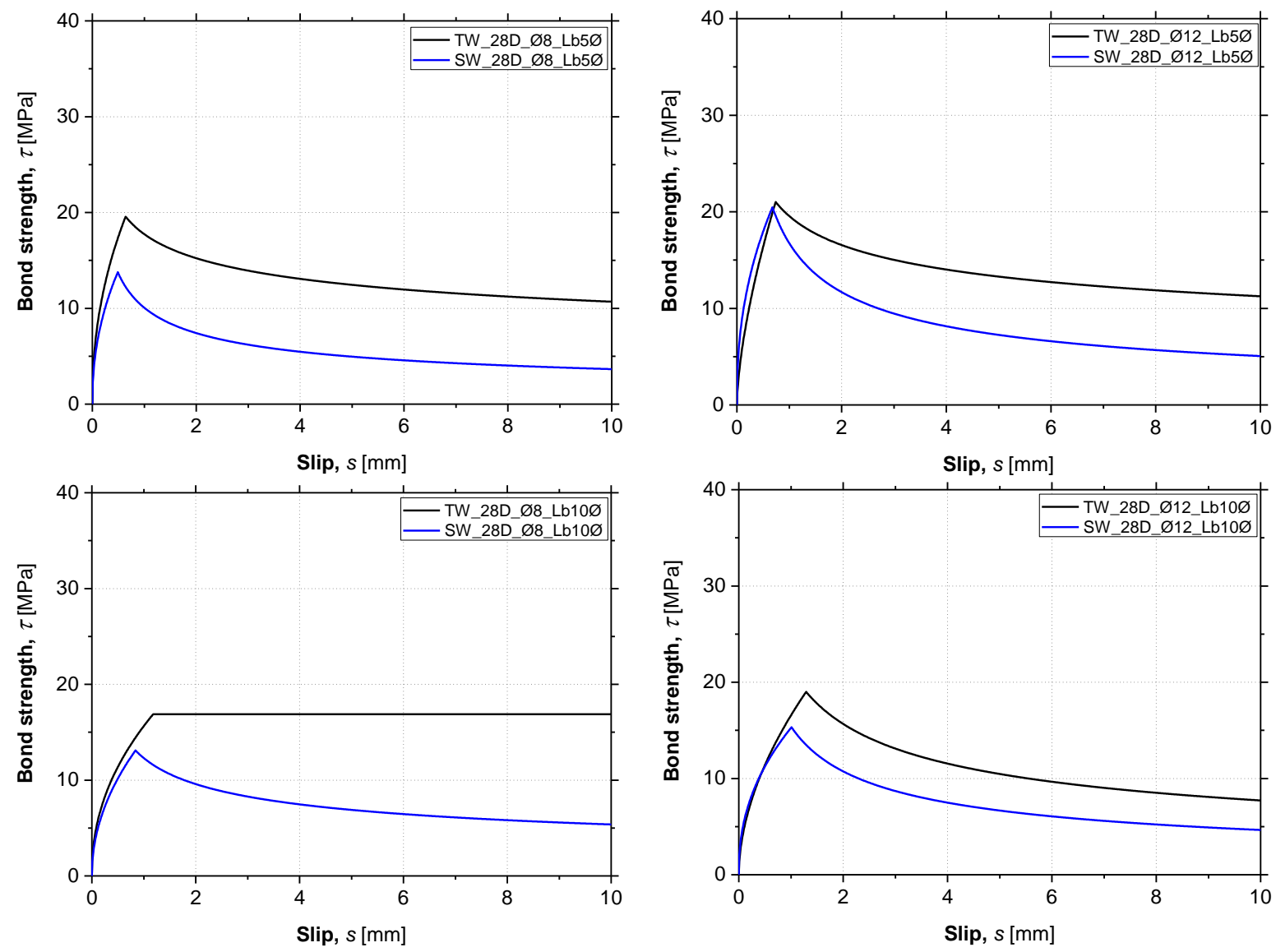

Figure 13 - Comparison of the local bond laws obtained in the inverse analysis.

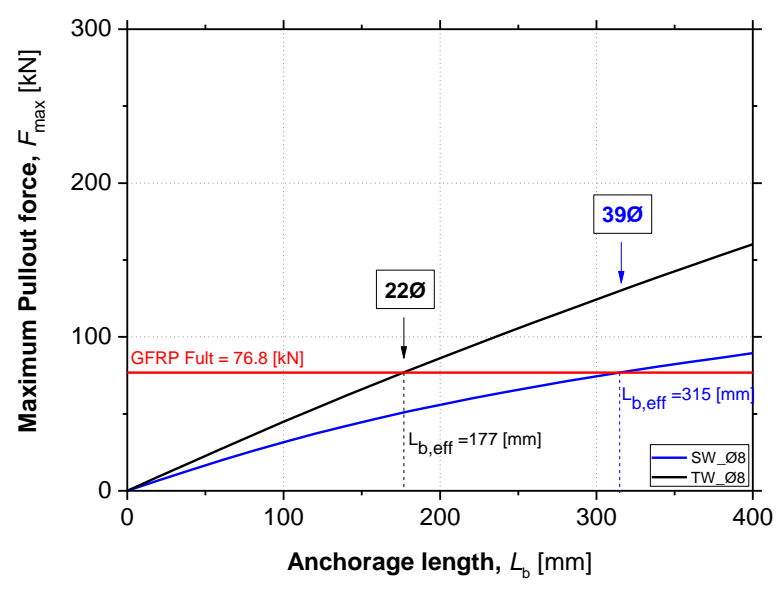

(a)

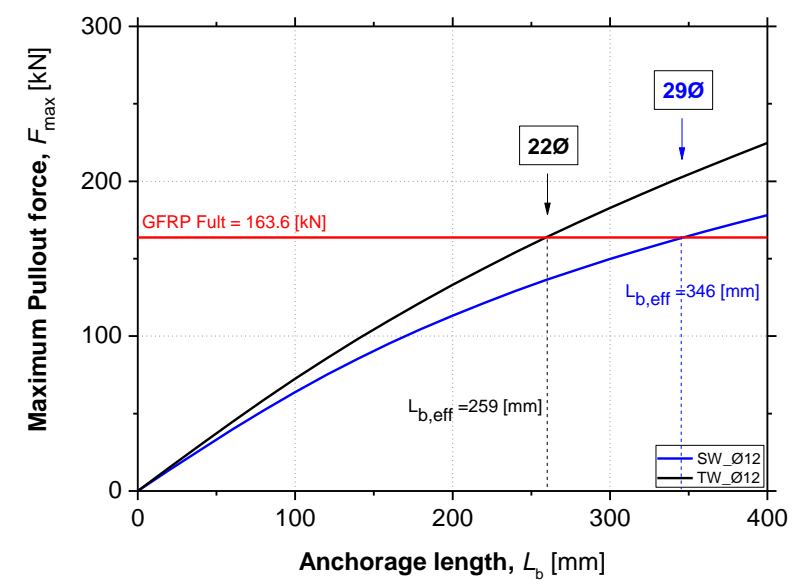

(b)

Figure 14 - Maximum pullout force versus anchorage length for GFRP rods of (a) Ø8 and (b) Ø12. 